\title{
EFFECTS OF PREDATOR FORAGING BEHAVIOR ON PATTERNS OF PREY MORTALITY IN MARINE SOFT BOTTOMS
}

\author{
FioRenZA MicheLI ${ }^{1}$ \\ University of North Carolina at Chapel Hill, Institute of Marine Sciences, Morehead City, North Carolina 28557 USA
}

\begin{abstract}
This study links spatial and seasonal patterns of mortality of the hard clam, Mercenaria mercenaria (L.), in marine soft bottoms with the predation rates and habitat use of its main predator, the blue crab, Callinectes sapidus Rathbun. Patterns of predation on tethered juvenile clams exposed to the natural assemblage of predators were compared among different habitat types in fall and summer. Between-habitat patterns of predation on clams varied with season. In fall, predation on tethered clams was greater in subtidal sand bottoms and just inside the edge of intertidal salt marshes than in intertidal sand flats. In summer, predation on clams was similar in all habitats. Experiments conducted in field enclosures showed that: (a) individual crabs spent more time in the salt marsh habitat than in intertidal sand flats; (b) crab individuals placed in a sand bottom habitat had greater predation rates in high-density prey patches than in low-density patches; (c) individuals had greater predation rates in prey patches located just inside the edge of salt marshes than in intertidal sand flats, when prey density was held constant between the two habitats; (d) at intermediate and high crab densities predation mortality of clams was similar between vegetated and unvegetated habitats; (e) both individual crabs and groups of crabs consumed similar numbers of clams in the two habitat types when large predatory birds (mainly various species of terns, Sterna spp., herring gulls, Larus argentatus Coues, and ring-billed gulls, L. delawarensis Ord) were excluded from enclosures, but the crabs consumed more clams in the salt marsh than in the sand flat habitat in control enclosures where birds were not excluded. In the fall, when Herring and Ring-billed Gulls were abundant in the study area, preference by blue crabs for safer and more profitable habitats may explain the greater predation on clams in salt marshes than in intertidal sand flats. In the summer, when Herring and Ring-billed Gulls were rare and crab densities are 1.5-3 times greater than in the fall, competition with conspecifics may have caused crabs to disperse and feed in intertidal flats and may explain the general lack of differences in predation intensity among habitat types observed in the summer. Thus, patterns of predation and habitat use by blue crabs appeared to explain between-habitat and seasonal differences in predation mortality of clams. Focusing on the variation in the feeding rates of individual predators in response to external conditions can produce the mechanistic understanding of spatial and seasonal patterns of predation needed to understand and better predict the processes that structure benthic marine communities.
\end{abstract}

Key words: bivalves; blue crabs; Callinectes sapidus; foraging theory; indirect effects; individualbased approach; intertidal; marine soft bottoms; Mercenaria mercenaria; predation.

\section{INTRODUCTION}

Predator-prey interactions have been studied from two perspectives. Community ecologists are primarily interested in the role of predators in determining the abundance, size structure, and distribution of their prey. Predation can affect community structure both directly, by imposing particular patterns of mortality upon prey populations (Paine 1966, Connell 1972, 1975, Sih et al. 1985), and indirectly, by modifying interactions among prey populations (Sih et al. 1985, Schoener 1993, Wootton 1993). In contrast, behavioral ecologists

Manuscript received 21 August 1995; revised 17 May 1996; accepted 13 June 1996; final version received 8 July 1996.

${ }^{1}$ Present address: National Center for Ecological Analysis and Synthesis, Santa Barbara, California 93101-3551 USA. are primarily interested in what factors determine the foraging choices made by predators. Most behavioral ecology studies of predator-prey interactions aim to predict what prey types and prey patches predators should select to maximize their fitness or some other variable that is assumed to be directly related to fitness, such as the net rate of energy intake (Pyke 1984, Stephens and Krebs 1986). Constraints operating on foragers in the real world, such as incomplete information about prey distribution (McNamara and Houston 1985, Bernstein et al. 1991), interference with competitors (Fretwell and Lucas 1970, Sutherland 1983), risk of predation (Milinski and Heller 1978, Sih 1980, Lima and Dill 1990), reproductive demands (Mangel and Clark 1988), avoidance of chemical deterrents in prey tissues (Hay and Fenical 1988), as well as complex interactions among different constraints (McNamara 
and Houston 1986, Peterson and Skilleter 1994, Skilleter and Peterson 1994) also affect a forager's behavior. Recent advances in modeling techniques allow incorporation of these constraints into foraging models (Houston et al. 1988, Mangel and Clark 1988). Most attention has been focused on whether such models yield accurate predictions about prey and prey-patch choices of foragers rather than on the consequences of such choices for prey populations and community structure.

An individual predator's decisions of where to feed and what prey to select can determine its impact on prey populations. The impact of predation on a community is the integrated result of the foraging activity of individual predators. Therefore, predictions about the impact that a predatory guild has on a community of prey may be derived from knowledge of the foraging behavior of individual predators and how this is affected by abiotic factors, prey distribution, competition with other foragers, and risk of predation by higher order predators. Understanding what factors influence the behavior of individual predators allows principles of behavioral ecology to be used to derive understanding and predictions about processes at higher levels of biological organization, i.e., at the population and community level.

The study of the behavior of a system at one level of complexity by focusing on the behavior of its components at a lower level of organization (e.g., an individual-based approach; DeAngelis and Gross 1992) allows an understanding of the mechanisms that interrelate the components of a system and produce observed patterns, thereby increasing predictive ability of what patterns are to be expected under different conditions (DeAngelis and Gross 1992, Levin 1992, Judson 1994, Goss-Custard et al. 1995a, $b$, but see Peters 1991). Over the last decade, an increasing number of ecologists have studied behavioral characteristics of predators and/or prey as a mechanistic basis for understanding the outcome of the interactions among members of aquatic communities. Many examples of this approach come from freshwater systems (Morin 1986, Kerfoot and Sih 1987, Mittelbach 1988, Gilliam et al. 1989, Kohler and McPeek 1989, Peckarsky and Penton 1989, Power et al. 1989, Power 1990, 1992, Werner 1992, Werner and McPeek 1994, Grill and Juliano 1996). Only a few examples of this approach are found in the marine ecological literature. In the rocky intertidal, the distribution and feeding rates of gulls (Irons et al. 1986) and of marine invertebrate predators (Robles 1987, Robles et al. 1995) were linked with the distribution of their prey. In an estuarine soft bottom, Eggleston et al. (1992) linked species-specific functional responses of individual blue crabs, Callinectes sapidus, preying upon infaunal clams in sandy and muddy sediments with the patterns of distribution of the clams Macoma balthica and Mya arenaria in the field. A limitation of this study was that functional responses of blue crabs were quantified in the laboratory, thereby eliminating the various abiotic and biotic variables that may affect a predator's foraging behavior in the field.

Here, I present the results of a study of predatorprey interactions in soft-sediment marine habitats conducted at two different scales, at the community and the individual levels. First, I described spatial and seasonal patterns of predation on a common infaunal bivalve, the hard clam Mercenaria mercenaria, exposed to the natural assemblage of predators in a lagoonal system of the eastern U.S. Second, I attempted to explain patterns of clam predation mortality by using an individual-based approach, by investigating the predatory behavior and habitat use of a key epibenthic predator in the study area, the blue crab Callinectes sapidus.

In estuarine and lagoonal soft bottom habitats, epibenthic predators are faced with variation in sediment types, amounts of structure (provided by vascular plants, algae, polychaete tubes, or other biogenic constructs), exposure to currents, and water depths. In addition to physical characteristics, habitats also differ in their biotic composition, including the abundance and quality of prey and the types and abundance of potential competitors and predators. Most habitat characteristics are also likely to vary through time. In the laboratory, blue crab predation rates on infaunal bivalves vary with prey species and sediment type (Lipcius and Hines 1986, Eggleston et al. 1992). Blue crabs have lower foraging efficiency when sediments contain shell debris, gravel, or seagrass rhizomes (Blundon and Kennedy 1982, Arnold 1984, Castagna and Krauter 1985, Sponaugle and Lawton 1990), and they show lower ability to detect infaunal bivalves in water flowing faster than $\approx 4.0 \mathrm{~cm} / \mathrm{s}$ and in turbulent flows (Weissburg and Zimmer-Faust 1993). Blue crabs are aggressive and cannibalistic (Jachowski 1974, Smith 1995), suggesting that intraspecific interference could affect their foraging efficiency. When faced with increasing densities of conspecifics in the laboratory, crabs spend increasing amounts of time engaged in aggressive interactions, resulting in decreased individual feeding rates (Mansour and Lipcius 1991). Blue crabs are also vulnerable to predation from predators such as larger conspecifics (Laughlin 1982, Hines et al. 1990), fishes (Moody 1994), and large birds such as herring and ring-billed gulls (Larus argentatus and L. delawarensis) (Prescott 1990) and herons (Ardea spp.) (T. G. Wolcott, personal communication). To avoid predation by visual predators, such as birds and fishes, crabs may tend to avoid structureless habitats. The feeding rates and habitat use of blue crabs are expected to vary in response to spatial and temporal changes in the abiotic and biotic characteristics of the habitats they utilize. Because blue crabs consume large numbers of bivalves (Hines et al. 1990, Peterson 1990, Eggleston et al. 1992), variability in how blue crabs distribute themselves and in where they concentrate their foraging activity may correspond 


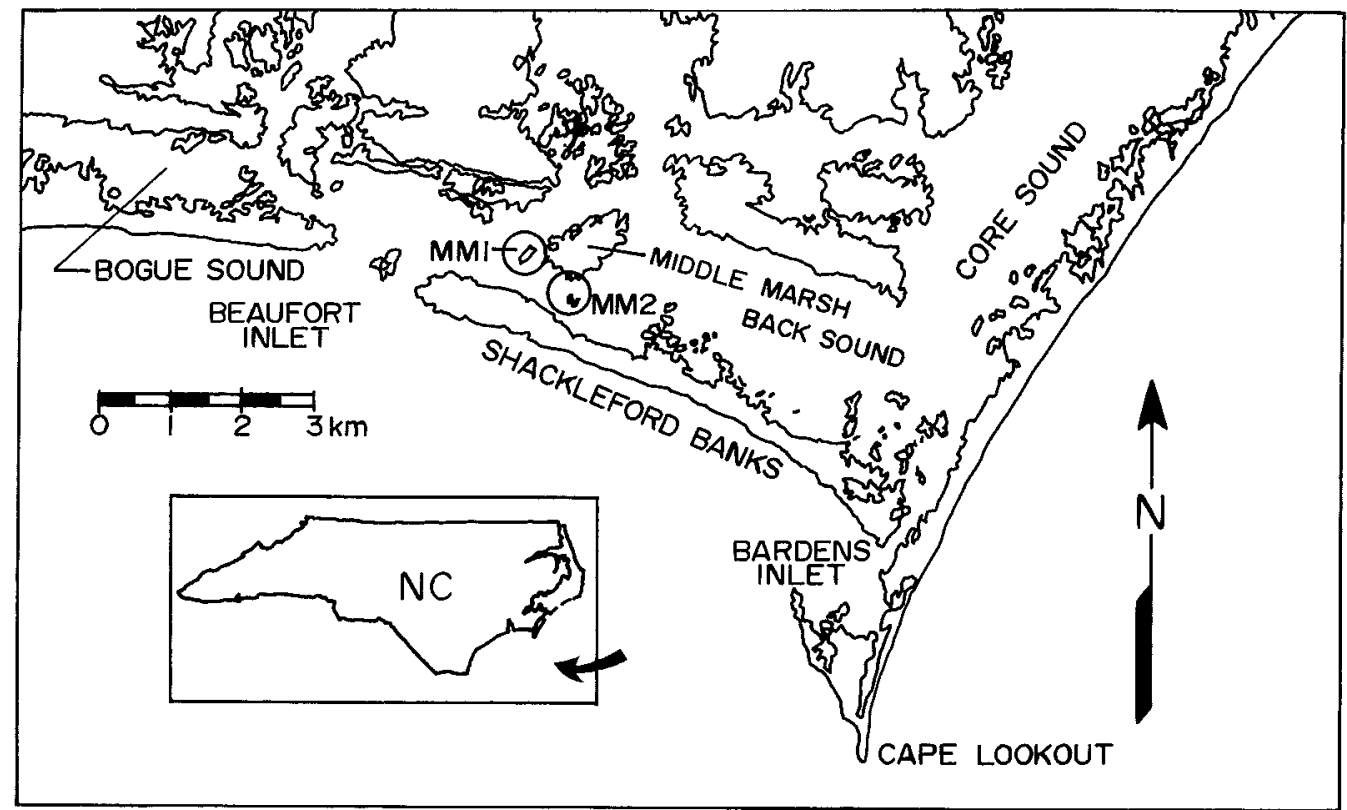

FIG. 1. Map of Back Sound, North Carolina, showing the location of the study sites within Middle Marsh: Middle Marsh site 1 (MM1) and Middle Marsh site 2 (MM2).

to mortality patterns of their prey and possibly influence the structure of benthic communities.

First, I compared predation rates on juvenile hard clams among different habitat types and seasons with tethering experiments. Second, I asked whether patterns of prey mortality could be explained by variation in the predation rates of the main clam predator in this system, the blue crab Callinectes sapidus. I conducted field enclosure experiments that examined the main and interactive effects of the following variables on predation rates of adult blue crabs feeding on hard clams: (1) prey density, (2) habitat structural complexity (i.e., presence or absence of emergent aquatic vegetation), (3) crab size, (4) crab density, and (5) risk of predation (from large birds). Third, I examined the effects of habitat structural complexity, tidal phase and time of the year on the habitat use of individual crabs within field enclosures.

\section{Methods}

\section{Study animals}

I chose the portunid crab Callinectes sapidus (the blue crab) as a model predator because it regulates the abundances and community structure of benthic organisms in estuarine and lagoonal systems of the eastern U.S. (Virnstein 1977, Woodin 1978, Blundon and Kennedy 1982, Hines et al. 1990). The blue crabs used in the experiments were caught with commercial crab pots deployed in the study area (Back Sound, North Carolina; Fig. 1). Crab pots are wire live traps $\approx 60 \times$ $60 \mathrm{~cm}$ wide and $50 \mathrm{~cm}$ high. Throughout this study, I used only intermolt male crabs that had both front claws and carapace width $(\mathrm{CW}$, measured from the tips of the lateral spines) between 100 and $150 \mathrm{~mm}$. The diet of crabs in this size range is composed of $30-50 \%$ infaunal bivalves, while other common prey items include gastropods, crabs, and fish (Laughlin 1982, Hines et al. 1990).

I chose the venerid clam Mercenaria mercenaria (the hard clam) as a model prey because it is common in the study area, is a common prey of blue crabs, and is distributed across several habitat types. All clams used in the experiments were hatchery raised (ARC, Atlantic, North Carolina, USA), and had an antero-posterior length of 1.3-2.5 cm. Clams in this size range are most vulnerable to predation by large blue crabs (Arnold 1984, Peterson 1990, Micheli 1995). Consumption of clams by blue crabs significantly declines for clams larger than $2.5 \mathrm{~cm}$ and even the largest crabs are rarely able to consume clams larger than $3.0 \mathrm{~cm}$ (Arnold 1984, Peterson 1990, Micheli 1995).

\section{Mortality patterns of juvenile hard clams}

I used tethering experiments to test for differences in mortality of juvenile clams among four habitat types and between two seasons, summer and fall. The four habitats were: a subtidal sand bottom always covered by $\geq 15 \mathrm{~cm}$ of water, a low-intertidal sand flat exposed only at spring low tides, a mid-intertidal sand flat exposed daily, and the edge of an intertidal salt marsh, also exposed daily (Fig. 2). These habitats were chosen to allow comparison of predation intensity between sand flats of different tidal elevation and also between vegetated and unvegetated habitats, holding tidal elevation constant. The experiment was replicated at two sites located on the northwestern (site MM1) and south- 


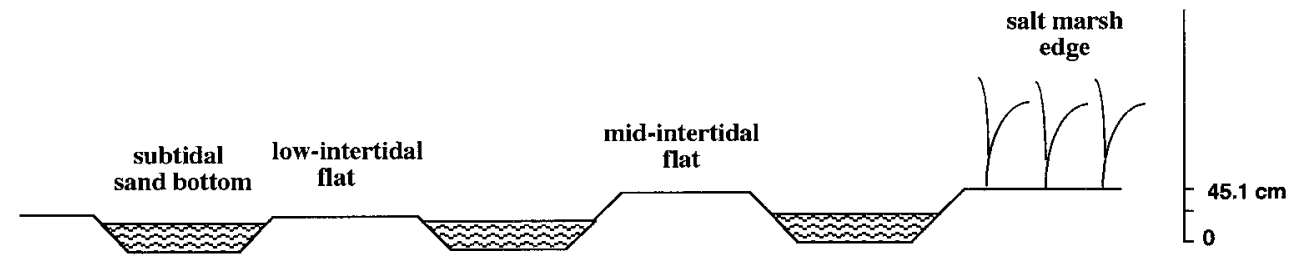

FIG. 2. Schematic profile of the study sites where tethering experiments were conducted. Predation mortality of juvenile clams was compared among four habitat types: subtidal sand bottoms, low- and mid-intertidal sand flats, and the edge of intertidal salt marsh islands.

ern (site MM2) sides of a group of salt-marsh islands (Middle Marsh, Back Sound, North Carolina; Fig. 1). Mean high water depths were $\approx 1.5 \mathrm{~m}$ on the subtidal sand bottoms, $1.2-1.3 \mathrm{~m}$ on the low-intertidal sand flats, and $1.0-1.1 \mathrm{~m}$ on both the mid-intertidal sand flats and the marsh edges. Salt marsh vegetation was composed of Spartina alterniflora (Loisel). S. alterniflora densities, based on shoot counts within seven haphazardly located $0.5-\mathrm{m}^{2}$ quadrats, averaged $19.0 \pm$ 2.6 and $17.1 \pm 2.6$ shoots $/ 0.5 \mathrm{~m}^{2}$ (mean $\pm 1 \mathrm{sE}$ in both cases) at sites MM1 and MM2, respectively. Plants were $1.0-1.5 \mathrm{~m}$ tall at most. Three replicate sediment cores $(5 \mathrm{~cm}$ in diameter, $5 \mathrm{~cm}$ deep) were taken at haphazard locations within each habitat for sediment grain-size analysis (Table 1). Sediment grain-size distribution was analyzed by dry sieving (Folk 1980).

Juvenile hard clams ranging between 12.5 and 19.4 $\mathrm{mm}$ in length (mean $\pm 1 \mathrm{SE}=15.2 \pm 0.1 \mathrm{~mm}$, based on a subsample of 100 clams) were marked with acrylic paint (Mark-Tex, Englewood, New Jersey, USA) to distinguish them from other clams and were tethered to $15 \mathrm{~cm}$ long metal staples with $15 \mathrm{~cm}$ long pieces of monofilament line $(4.5 \mathrm{~kg}$ test). The end of the line was placed on one valve of the shell and covered with a drop of cyanoacrylate glue and a small piece of electrical tape. Clams were deployed in the field along 7.4 $\mathrm{m}$ long strings placed along a constant depth contour. In the salt marsh habitat, clams were deployed $\approx 0.5$ $m$ from the edge of the vegetation. Ten clams were spaced $0.8 \mathrm{~m}$ apart along each string. Clams were spaced in this fashion because natural clam densities in the study area were low, averaging 0.2-1.6 individuals $/ \mathrm{m}^{2}$ in sand flats (Peterson et al. 1984; F. Micheli, unpublished data) and 3.5 individuals $/ \mathrm{m}^{2}$ along the marsh edges (F. Micheli, unpublished data). Clams were buried in living position flush with the sediment surface and metal staples were anchored beneath the sediments. Five replicate strings were set up in each habitat type, at each site, yielding a total of 40 strings.

After $1 \mathrm{wk}$, clams were retrieved from the strings and were scored as (1) live, (2) dead with intact valves (possibly killed by physical stress, disease, or parasitism; Peterson 1982), (3) dead with crushed or chipped valves, (4) dead with drilled valves or with valves filed at the edges, or (5) missing. Based on laboratory trials, mortality in category 3 was attributed to crabs (mainly the blue crab Callinectes sapidus, the stone crab Menippe mercenaria Say, and the mud crab Panopeus herbstii H. Milne Edwards). Mortality in category 4 was attributed to predation by the gastropods Polinices duplicatus (Say 1822) (the moon-snail), and Busycon spp. (whelks), respectively (Peterson 1982). It was assumed that missing clams had been carried away by predators because tethers prevented clams from actively migrating from their initial location. Because crabs were commonly seen carrying clams off before

TABle 1. Sediment characteristics in Back Sound, North Carolina, in the four habitat types where clam-tethering experiments were conducted (a), and in the two habitat types within the first and second set of rectangular enclosures (b).

\begin{tabular}{|c|c|c|c|c|c|c|c|c|}
\hline \multirow[b]{2}{*}{ Particle class } & \multicolumn{2}{|c|}{$\begin{array}{c}\text { Subtidal } \\
\text { sand bottom }\end{array}$} & \multicolumn{2}{|c|}{$\begin{array}{l}\text { Low-intertidal } \\
\text { sand flat }\end{array}$} & \multicolumn{2}{|c|}{$\begin{array}{l}\text { Mid-intertidal } \\
\text { sand flat }\end{array}$} & \multicolumn{2}{|c|}{ Salt marsh edge } \\
\hline & Site MM1 & Site MM2 & Site MM1 & Site MM2 & Site MM1 & Site MM2 & Site MM1 & Site MM2 \\
\hline $\begin{array}{l}\text { Silt-clay } \\
\text { Very fine sands }\end{array}$ & $\begin{array}{r}1.8(0.1) \\
91.9(0.8)\end{array}$ & $\begin{array}{r}2.1(0.6) \\
92.6(1.2)\end{array}$ & $\begin{array}{r}2.3(0.2) \\
91.8(0.7)\end{array}$ & $\begin{array}{r}0.7(0.1) \\
91.6(1.0)\end{array}$ & $\begin{array}{r}1.2(0.2) \\
97.1(0.3)\end{array}$ & $\begin{array}{r}2.2(0.4) \\
89.1(1.1)\end{array}$ & $\begin{array}{r}5.2(0.1) \\
79.8(1.4)\end{array}$ & $\begin{array}{r}5.6(0.2) \\
89.9(0.9)\end{array}$ \\
\hline
\end{tabular}

b) Enclosure experiments

\begin{tabular}{lcccccc} 
& \multicolumn{2}{c}{ Intertidal sand flat } & & \multicolumn{2}{c}{ Intertidal salt marsh } \\
\cline { 2 - 3 } \cline { 5 - 6 } Particle class & First set & Second set & & First set & Second set \\
\hline Silt-clay & $1.5(0.4)$ & $7.04(1.0)$ & & $2.2(0.4)$ & $10.1(0.9)$ \\
Very fine sands & $81.1(5.2)$ & 86.6 & $(1.3)$ & & $87.3(5.2)$ & $81.9(1.6)$
\end{tabular}

Notes:Very fine sands (grain sizes $62.5-125 \mu \mathrm{m}$ ) were the dominant size fraction in all habitats. Percentage silt and clay $(<62.5 \mu \mathrm{m})$ is also reported. For the tethering experiments, average percentages (by mass) of three replicate samples are reported. For the enclosure experiments, percentages are averages of four samples taken from the four $30-\mathrm{m}^{2}$ enclosures (first set) and of six samples taken from the six $25.5-\mathrm{m}^{2}$ enclosures (second set). Data are means with $1 \mathrm{SE}$ reported in parentheses. 
attempting to crush them but predatory snails seemed to consume clams in situ (F. Micheli, personal observations), missing clams were probably due mostly to crab predation. However, other potential clam predators might have carried clams away. For example, cownose rays (Rhinoptera bonasus (Mitchill)) can also prey heavily upon clams at some locations and times of the year (Peterson 1990, Eggleston et al. 1992). Missing clams were analyzed as a separate category from dead clams with chipped or crushed shells (predation attributed to crabs) because the cause of missing clams was not ascertained. Total $\%$ predation was determined for each string by adding the percentage of clams dead with predation marks on their shells and the percentage of clams missing. This experiment was conducted in the summer (6-13 July) and fall (13-21 October) of 1993.

Percentage of deployed clams found dead with undamaged valves, percentage dead with chipped or crushed valves (predation attributed to crabs), percentage dead with drilled or filed valves (predation attributed to gastropods), percentage of clams missing, and total percentage predation were compared between the sites and among the different habitat types and seasons with separate three-way ANOVAs. The assumption of homoscedasticity was tested with Cochran's test (at $\alpha=0.05$ ). When necessary, data were arcsine-transformed to achieve homoscedasticity. Site (site MM1 and site MM2), habitat type (subtidal sand bottom, lowintertidal flat, mid-intertidal flat, and intertidal salt marsh edge), and season (summer and fall) were considered fixed factors in the ANOVAs. Because the assumption of homoscedasticity was met and each treatment combination had an equal number of replicates, treatment means were compared, after ANOVA, with the Student-Newman-Keuls (SNK) procedure (at $\alpha=$ 0.05) (Day and Quinn 1989).

To assess whether handling associated with tethering of the clams increased their mortality, tethered and untethered clams were enclosed within predator exclusion cages $(30 \times 30 \times 15 \mathrm{~cm})$ built with $6-\mathrm{mm}$ Vexar mesh (Internet, Minneapolis, Minnesota, USA). Each cage received either 10 tethered or 10 untethered clams. At the beginning of each experiment, four cages were deployed on the sediment surface at each site in the subtidal sand bottom habitat. At each site, two replicate cages contained tethered clams and the other two contained untethered clams. Percentage mortality of clams in the cages was analyzed with three-way ANOVA with site (site MM1 and site MM2), clam-tethering treatment (tethered and untethered), and season (summer and fall) as the fixed factors.

\section{Seasonal patterns of blue crab abundance}

To determine whether the abundance of blue crabs, and thus the potential for intraspecific competition, varied with season, I estimated an index of relative abundance of crabs in the study area twice a month from
May 1992 until December 1993 by deploying commercial crab pots at both field sites (Fig. 1). Crabs $<80$ $\mathrm{mm}$ in carapace width could escape through the trap mesh and were rarely found in the crab pots. The smallest crab captured measured $60 \mathrm{~mm}$ in carapace width. Therefore, this sampling technique quantified only relative abundances of subadult and adult crabs. On each date, five crab pots were baited with pieces of fish, deployed haphazardly in the subtidal sand bottom habitat at each of the two field sites, and retrieved after 24 h. Crabs were counted, measured, and released at the same location. Sampling was always conducted during spring tides because pilot sampling indicated that crab abundances were greatest at this tidal phase (F. Micheli, unpublished data). The average number of crabs per trap at each sampling was plotted against date to detect seasonal patterns in relative crab abundance in the study area.

\section{Experimental protocol of enclosure experiments}

To investigate the effects of external conditions on the predation rates of adult blue crabs on hard clams, I conducted a suite of experiments within three sets of field enclosures (circular 30- $\mathrm{m}^{2}$ enclosures, rectangular $30-\mathrm{m}^{2}$ enclosures, and rectangular $25.5-\mathrm{m}^{2}$ enclosures; for detailed description of enclosures, see next three subsections of Methods). The same general experimental protocol was used to investigate the effects of the following factors on predation rates of adult blue crabs on juvenile hard clams: (1) prey density, (2) the presence of emergent aquatic vegetation, (3) crab size, (4) crab density, and (5) risk of predation on crabs by birds. These factors were chosen as the most likely ones to affect the predation rates of blue crabs on clams and they exhibited obvious patterns of variation among habitat types (factors 1 and 2; F. Micheli, unpublished data) and between seasons (factors 3, 4, and 5; Peterson 1990, Prescott 1990, Fitz and Wiegert 1991, Eggleston et al. 1992).

In all experiments, individual crabs or groups of crabs held within the enclosures were offered two prey patches. Prey patches differed in the density of clams that they contained, in their structural complexity (e.g., with or without salt marsh plants), or both. I constructed two prey patches in each enclosure by deploying a known number of juvenile hard clams within $1-\mathrm{m}^{2}$ quadrats previously cleared of pre-existing prey. Clams were pushed in the sediments to their living position, with their posterior end flush with the sediment surface. Pre-existing prey had been removed by examining the sediment surface and then plowing sediments with fingers to a depth of $\approx 10 \mathrm{~cm}$. Prey that burrowed deeper, such as the clam Macoma balthica, might have been left in the patches. Quadrats were marked with two steel stakes located at opposite corners and were 2.5 to $4.0 \mathrm{~m}$ apart from each other, depending on the set of enclosures where the experiment was conducted. Following Charnov (1976), I assumed that a crab con- 
sumes prey at one prey patch, experiencing diminishing returns through time, until harvesting that patch becomes unprofitable and greater returns can be achieved by moving to another prey patch. The proportion of prey consumed at each patch was used as a measure of the prey-patch use by the crabs.

Because the number of enclosures available was not sufficient to run all replicate trials concurrently, replication was obtained by repeating trials on different dates. Date was added as a blocking factor in all statistical analyses (see Methods: Statistical analyses of enclosure experiments, below). Each trial generally lasted 1-3 d. The duration of trials depended on weather conditions, which dictated my ability to reach the field site. Also, crabs seemed to have an "all-or-nothing" response to food patches, in that they often did not feed within 1-2 d of the beginning of the experiment, but ate a substantial amount of clams within a few hours once their feeding started. Therefore, trials were ended when crushed clam shells were seen in the enclosures, indicating that feeding had occurred. To facilitate clam recovery, clams were deployed at the intersections of a monofilament-line grid supported by a polyvinyl chloride plastic (PVC) frame. Thus, clams were regularly spaced within patches and could be easily found at the end of each trial (unless crabs had carried them off before eating them) by superimposing the grid on the patches and finger-plowing sediments at the grid intersections.

At the beginning of each trial, marked crabs were introduced to randomly drawn enclosures. At least one enclosure did not receive any crabs and served as a control for clam mortality due to causes other than blue crab predation. At the end of each trial, marked crabs were captured with a dip-net or a crab pot and a new trial was started. Throughout this study, crabs were never reused in the experiments and replicate trials were excluded from analyses if other potential clam predators (whelks, stone crabs, or blue crabs $>70 \mathrm{~mm}$ in carapace width [other than individuals added as part of this experiment; smaller blue crabs are unable to crush clams in the size range used in these experiments]; Peterson 1990) were found in enclosures at the end of trials. The number of replicates frequently differed among treatments as a result of having to eliminate some replicates.

Upon termination of each experimental trial, I retrieved live clams and crushed shells from all enclosures by plowing each patch with fingers to a depth of $\approx 10 \mathrm{~cm}$. Most clams were either missing or were recovered with their valves crushed or chipped at the edges. A few clams were also missing in the control enclosures in most experimental trials. Missing clams might have been lost due to sampling error, have migrated from the patches, have been washed off after death, or have been carried away from the patch by crabs. In fact, crushed and chipped clam valves were frequently found away from the patches, particularly along the enclosure edges.

Throughout this study, the number of dead clams with predation marks on their shells and the number of missing clams from each patch were pooled for analyses because it was not possible to discriminate among the possible causes of missing clams. In enclosures containing crabs, missing clams were attributed to crab predation, clam migration, or passive transport out of the patches, and sampling error. In the control enclosures, missing clams were attributed to all of these causes except crab predation. I assumed that factors causing missing clams were identical between enclosures with and without crabs, with the exception of crab predation. Therefore, statistical comparison of clam losses between the predator and control enclosures allowed for separation of the effects of crabs from other factors underlying clam losses, such as clam migration or sampling error. The assumption that clam migration and sampling error were identical between predator and control enclosures might be challenged on the grounds that the presence of crabs could have affected the clam behavior, for example by causing clams to burrow deeper in the sediments to escape crab predation and thus being more likely to be missed during sampling. However, although hard clams have been reported to decrease their feeding time in the presence of whelks (Irlandi and Peterson 1991; M. Nakaoka, personal communication), there are no data indicating that their movements are affected by the presence of predators.

\section{Effect of prey density}

Blue crabs foraging in intertidal and shallow-subtidal soft bottoms commonly encounter habitats and prey patches characterized by markedly different prey densities. In the study area, densities of blue crab benthic prey are 10-30 times greater along the edge of intertidal salt marshes than in adjacent unvegetated sand flats (F. Micheli, unpublished data). I conducted an enclosure experiment to test the hypothesis that crab predation on clams is density dependent and that crabs consume proportionally more clams at high-density than at low-density prey patches. Two circular field enclosures $\left(30 \mathrm{~m}^{2}\right.$ each) were built on a sandy bottom in Bogue Sound, North Carolina (Fig. 1). Enclosures with walls $1.5 \mathrm{~m}$ high were built with $8-\mathrm{mm}$ Vexar mesh supported by steel stakes. The enclosure walls were buried $15 \mathrm{~cm}$ into the sediments to prevent crabs from escaping. Water depth ranged from $20-30 \mathrm{~cm}$ at low tides to $1.2-1.3 \mathrm{~m}$ at high tide. Larger shell debris and benthic animals, such as whelks (Busycon spp.), moon-snails (Polinices duplicatus), and spider crabs (Libinia emarginata), were removed before starting the experiments by raking the sediments to a depth of $\approx 5$ $\mathrm{cm}$. Juvenile hard clams used in this experiment ranged from 15.3 to $23.5 \mathrm{~mm}$ in length (mean $\pm 1 \mathrm{SE}=19.2$ $\pm 0.33 \mathrm{~mm}$, based on a subsample of 50 clams). Within 
each enclosure, clams were deployed at high density (50 individuals $/ \mathrm{m}^{2}$ ) at one patch and at low density (10 individuals $/ \mathrm{m}^{2}$ ) at the other patch. The two prey patches were $\approx 2.5 \mathrm{~m}$ apart. Densities used in the experiments were greater than natural clam densities in the study area (see Methods: Mortality patterns of juvenile hard clams, above). However, average densities as high as 30 clams $/ \mathrm{m}^{2}$ have been reported for other areas (MacKenzie 1977). Moreover, clams were used in these experiments as model prey to mimic the situation of crabs encountering patches of different prey abundances.

Replication was obtained by repeating the experiment over time within the same enclosures during the fall of 1992. At the beginning of each trial, one randomly assigned enclosure received one blue crab (117.5-140.0 mm carapace width, mean $\pm 1 \mathrm{SE}=127.6$ $\pm 3.4 \mathrm{~mm}, n=7 \mathrm{crabs})$. The other enclosure acted as a control for clam mortality in the absence of crabs. Crabs were caught 2-4 d before the start of each trial and were kept in laboratory aquaria equipped with flowing seawater. All crabs were starved for $48 \mathrm{~h}$ before introducing them into an enclosure. Each experimental trial lasted 1-2 d.

\section{Effects of habitat structural complexity and crab size}

Because predation on tethered juvenile clams tended to be greater just inside the edge of salt marshes than in intertidal sand flats of similar tidal elevation (see Results: Mortality patterns of juvenile hard clams; Micheli 1996), I conducted an enclosure experiment to test the hypothesis that individual blue crabs have greater feeding rates in salt-marsh habitats than in intertidal sand flats. Four rectangular enclosures were built with 8-mm Vexar mesh supported by wooden posts at site MM1, in Middle Marsh (Fig. 1). Enclosures were $10 \mathrm{~m}$ long, $3 \mathrm{~m}$ wide, and $1.1 \mathrm{~m}$ tall, and were built with their longest sides perpendicular to the edge of a salt marsh so that they enclosed equal areas of salt marsh and adjacent tidal flat. Enclosure walls were buried $15 \mathrm{~cm}$ into the sediments. At high tides, the water within the enclosures was $\approx 1 \mathrm{~m}$ deep, while at most low tides both vegetated and unvegetated portions were exposed. A hole $(\approx 50 \mathrm{~cm}$ in diameter, 30 $\mathrm{cm}$ deep) was dug in the middle of each enclosure, at the edge between the salt marsh and the sand flat, to provide a water-filled refuge for the crabs at low tide. To prevent excessive heating of the water inside the pits, each hole was covered with a wooden roof elevated $\approx 40 \mathrm{~cm}$ from the substrate. Due to the slope of the shore, the centers of the marsh portion of the enclosures were, on average, $12.7 \pm 3.7 \mathrm{~cm}$ higher (mean $\pm 1 \mathrm{SE} ; n=4$ enclosures) than the centers of the sand flat portion. Plant densities were determined by counting Spartina alterniflora shoots within two $0.5-\mathrm{m}^{2}$ quadrats haphazardly placed within the vegetated portion of each enclosure (mean $\pm 1 \mathrm{SE}=43.5 \pm 4.9$ shoots $/ 0.5 \mathrm{~m}^{2}, n=8$ quadrats $)$. A sediment core $(5 \mathrm{~cm}$ wide, $5 \mathrm{~cm}$ deep) was taken from the center of both the vegetated and unvegetated portion of each enclosure for sediment grain-size analysis (Folk 1980) (Table 1). Before the start of the experiment, enclosures were checked visually for several consecutive days and all animals found (American oysters, Crassostrea virginica Gmelin; hard clams, Mercenaria mercenaria; marsh periwinkles, Littoraria irrorata Say; mud snails, Ilyanassa obsoleta Say; fiddler crabs, Uca spp.; and juvenile blue crabs, C. sapidus) were removed to minimize alternative prey available to the crabs within enclosures.

This experiment was conducted by repeating trials over time within the same enclosures in the fall of 1993. At the beginning of each trial, 20 clams (size range 13.0-20.3 mm [mean $\pm 1 \mathrm{SE}=15.7 \pm 0.23 \mathrm{~mm}$, based on a subsample of 50 clams]) were deployed in each of two $1-\mathrm{m}^{2}$ patches, one in the middle of the vegetated portion of each enclosure and the other in the middle of the unvegetated portion. On each trial, one enclosure served as control with no crabs added, while predator enclosures received one crab each. To determine whether crabs of different sizes responded to the presence of vegetation differently, two size classes of crabs were used: small (102.6-117.0 mm [mean $\pm 1 \mathrm{SE}=109.4$ $\pm 1.55 \mathrm{~mm}], n=9 \mathrm{crabs})$ and large $(127.4-140.0 \mathrm{~mm}$ [135.4 $\pm 1.44 \mathrm{~mm}], n=12$ crabs). Treatments (no crab, small crab, or large crab added) were randomly assigned to specific enclosures. Crabs were released into the experimental enclosures within 1-2 $\mathrm{h}$ after being captured in crab pots.

After 1-6 d (but most commonly 1-3 d) from the beginning of each trial, live clams and crushed shell were recovered from each prey patch. Each enclosure was visually searched at low tide and crabs were captured and released.

\section{Effects of habitat structural complexity and crab density}

Trapping of blue crabs in the study area showed that crab abundance varied greatly among seasons (see $R e$ sults: Seasonal patterns ...). The effects of crab density on predation rates by blue crabs on clams in vegetated and unvegetated habitats were investigated in the four field enclosures described above. This experiment was conducted between late July and early September of 1993. Four crab-density treatments were used: zero, one, three, and six crabs/enclosure, corresponding to densities of $0,0.03,0.1$, and $0.2 \mathrm{crabs} / \mathrm{m}^{2}$. These densities were chosen to bracket the range of natural blue crab densities of $0.02-0.2 \mathrm{crabs} / \mathrm{m}^{2}$ reported by Fitz and Wiegert (1991) in a similar system (Sapelo Island, Georgia, USA). Crabs used in this Middle Marsh, Back Sound, North Carolina (Fig. 1) experiment ranged between 98.0 and $139.0 \mathrm{~mm}$ in carapace width (mean $\pm 1 \mathrm{SE}=121.7 \pm 0.9 \mathrm{~mm}, n=$ 137 crabs). Crabs assigned to the intermediate- and high-density treatments were matched by size as close- 
ly as possible in the attempt to form groups of crabs with similar competitive abilities.

Sampling of benthic invertebrates in the study area had shown that blue crab prey, mainly molluscs and crustaceans, are 10-30 times more abundant in salt marshes than in intertidal sand flats (F. Micheli, unpublished data). To mimic the pattern of relative prey abundances encountered by blue crabs in these two habitats, clams (size range 13.0-20.3 mm [mean \pm 1 $\mathrm{SE}=15.7 \pm 0.23 \mathrm{~mm}]$, based on a subsample of 50 clams) were deployed in the vegetated patches at densities 10 times greater $\left(100 \mathrm{clams} / \mathrm{m}^{2}\right)$ than in the unvegetated patches $\left(10 \mathrm{clams} / \mathrm{m}^{2}\right)$. At the beginning of each trial, the four crab-density treatments were randomly assigned to specific enclosures. To test whether prey distribution alone explained patterns of predation by blue crabs, this experiment was also repeated deploying clams at densities 10 times greater in the unvegetated than in the vegetated patch (i.e., 100 clams/ $\mathrm{m}^{2}$ in the sand flats, 10 clams $/ \mathrm{m}^{2}$ in the salt marsh). Trials with different distributions of prey between the two habitats were randomly interspersed. After 1-6 d from the beginning of each trial, clams and crabs were retrieved from each enclosure as described above. Trials were repeated until 6-8 replicates per treatment were available.

\section{Effects of predation risk and crab density}

Large birds (most commonly various species of terns [Sterna spp.], and gulls [Larus spp.], occasionally also blue herons [Ardea herodias], great egrets [Casmerodius albus], snowy egrets [Egretta thula], white ibises [Eudocimus albus], and brown pelicans [Pelecanus occidentalis]) were commonly seen hovering over the enclosures, perching on the wooden posts supporting the fences, or walking on the sand flat, both inside and outside the enclosures. Herring and ring-billed gulls (Larus argentatus and L. delawarensis), two reported predators of blue crabs (Prescott 1990), were particularly common in the fall (Peterson 1990, Prescott 1990; F. Micheli, personal observations). Crabs may see the birds through the shallow water covering intertidal flats, particularly during rising and falling tides, and may respond to this potential threat by reducing their feeding rates in this habitat type. The hypothesis that habitat-specific risk of predation alters the pattern of blue crab predation on clams between vegetated and unvegetated intertidal habitats was tested within six field enclosures that were built at a different location within site MM1. On each experimental trial, birds were excluded from three enclosures, while three enclosures where birds were not excluded served as controls. Bird exclosures and control enclosures were alternated on different trials. Each enclosure received zero, one, or three adult male crabs (size range: 97.0 $144.0 \mathrm{~mm} \mathrm{CW}$ [mean $\pm 1 \mathrm{sE}=125.2 \pm 1.43 \mathrm{~mm}$ ], $n$ $=57$ crabs), corresponding to crab densities of $0,0.04$, and $0.1 \mathrm{crabs} / \mathrm{m}^{2}$. Crab-density treatments were as- signed at random to specific enclosures. During each trial, six treatment combinations were orthogonally applied: three levels of crab density (zero, one, or three crabs/enclosure) and two levels of bird density (with or without birds). This experimental design allowed for a test of the effects of crab density and bird density (i.e., bird-exclusion treatment) separately, as well as their interaction, on predation rates on clams in vegetated and unvegetated habitats.

Enclosures were constructed in a way similar to those described above (see Methods: Effect of habitat structural complexity and crab size) but were slightly smaller ( $8.5 \mathrm{~m}$ long, $3.0 \mathrm{~m}$ wide, and $1.3 \mathrm{~m}$ high). In addition, water depths were greater $(\leq 1.1 \mathrm{~m})$, the difference in elevation between the vegetated and unvegetated portions of the enclosures was less (mean $\pm 1 \mathrm{SE}=0.9$ $\pm 0.35 \mathrm{~cm}, n=6$ enclosures), plant densities were lower $\left(29.5 \pm 4.25\right.$ shoots $/ 0.5 \mathrm{~m}^{2}, n=6$ quadrats $)$, and sediments had a greater percentage of silts and clays (Table 1). New enclosures were built for this experiment because the enclosures used for the experiments described above had been damaged by winter storms. This experiment was conducted between late September and late October of 1994. At the beginning of each trial, $1-\mathrm{m}^{2}$ patches of clams (size range: $14.6-23.0 \mathrm{~mm}$ $[$ mean $\pm 1 \mathrm{sE}=20.2 \pm 0.3 \mathrm{~mm}$ ], based on a subsample of 50 clams $)$ of equal density $\left(20 \mathrm{clams} / \mathrm{m}^{2}\right)$ were created in the centers of the vegetated and unvegetated portions of the six enclosures. Bird exclusion was achieved by securing two 5-m long pieces of "Scareaway bird line" (Grow Craft International, Vista, California, USA) to the wooden posts and stretching them diagonally over both the vegetated and unvegetated portions of each enclosure. The bird line is a plastic ribbon that vibrates in the wind producing a noise that scares birds away up to $4 \mathrm{~m}$ from either side of the line. Preliminary observations indicated that some terns would perch on enclosures even in the presence of the bird line, particularly when winds were calm. To further prevent birds from perching on the posts, steel stakes were secured to the end of the wooden posts so that there was a $10-15 \mathrm{~cm}$ long spike at the end to each post. On two occasions all birds hovering over each enclosure or perching along their edges were counted every $5 \mathrm{~min}$ for $2 \mathrm{~h}$. Bird counts were conducted using binoculars from a small boat anchored $\approx 100 \mathrm{~m}$ away from the enclosures. The effectiveness of the bird exclusion was tested by comparing the number of birds between bird exclusions and controls. The difference in bird abundances between bird exclosures and controls was so dramatic that no statistical analysis was necessary (see Fig. 9).

\section{Statistical analyses of enclosure experiments}

All enclosure experiments investigating predation rates of blue crabs on clams under different conditions were analyzed in a similar way. ANOVA was used in all cases. In the experiments where prey patches had 
equal initial clam densities, the dependent variable in the ANOVAs was the difference in the numbers of clams preyed upon between vegetated and unvegetated patches. Differences provided indexes of the crabs' relative use of the two patches that circumvented the problem of the non-independence of predation rates at the two patches in these choice experiments (Peterson and Renaud 1989). In the experiments where prey patches had different initial densities, the dependent variable in the analyses was the difference in the proportions of clams preyed upon between high- and low-density patches.

Differences in predation rates between the two patches were analyzed with a $t$ test comparing the control and predator treatments, or with one-way ANOVA models when more than two treatments were compared. In the last experiment (Methods: Effects of predation risk and crab density), differences in predation rates between the two patches were analyzed with a twoway ANOVA, with crab density and bird density as fixed factors. One- or two-way ANOVA models were also used with the total numbers of clams missing or crushed in each enclosure as the response variable. This allowed me to establish whether the addition of predators to the enclosures had a significant effect on the overall clam losses in the enclosures.

Date was added as a blocking factor in all analyses because experiments were replicated at different dates. When the effect of date was not significant (using the conservative probability level of $\alpha=0.25$; Underwood 1981), the analysis was repeated after pooling the different dates. The use of differences between predation rates at the two patches resulted in both positive and negative response values. Because of the presence of negative numbers in the data sets, transformation of the data could not be carried out and all analyses were performed on untransformed data. The assumption of homoscedasticity was tested with Cochran's test (at $\alpha$ $=0.05$ ). This test indicated that variances of treatment groups in several analyses were heteroscedastic and therefore one of the assumptions of ANOVA was violated. However, ANOVA is generally not strongly affected by violation of the assumption of homoscedasticity (Underwood 1981, Day and Quinn 1989). When the assumption of homoscedasticity was not met, treatment means were compared, after ANOVAs, with the Games-Howell procedure (at $\alpha=0.05$ ) (Day and Quinn 1989). When the assumption of homoscedasticity was met, treatment means were compared with the Kramer's modification of Tukey's test (at $\alpha=0.05$ ), correcting for unequal numbers of replicates per treatment (Day and Quinn 1989).

\section{Use of vegetated and unvegetated habitats by blue crabs}

Enclosure experiments investigating the effects of the presence of emergent aquatic vegetation on predation rates of blue crabs indicated that individual blue crabs had greater predation rates in vegetated (salt marsh) than unvegetated (intertidal sand flat) habitats (see Results: Effects of habitat structural complexity and crab size). To test whether this predation pattern was caused by a blue crab preference for vegetated habitats, I quantified the use of the salt-marsh and intertidal sand-flat habitat by blue crabs by direct observation of the proportion of time that individual crabs spent within each habitat type in the field enclosures. Observations were conducted on 19 and 27 October 1993 within the set of four $30-\mathrm{m}^{2}$ enclosures, and on 13 and 21 June and 6 and 13 July 1994 within the set of six $25.5-\mathrm{m}^{2}$ enclosures. On these dates, maximum water temperatures inside the enclosures were $23.9^{\circ}$, $18.9^{\circ}, 27.8^{\circ}, 31.7^{\circ}, 31.1^{\circ}$, and $30.6^{\circ} \mathrm{C}$, respectively. All observations started after sunset, when blue crabs are reported to be most active (Nye 1990). Just before sunset, crabs were captured in crab pots. A red cyalume glow stick (Hi-Seas, New York, New York, USA) was glued to their carapace, perpendicular to the anteroposterior axis, with a 5-min epoxy adhesive (Devcon, Danvers, Massachusetts, USA). Glow sticks measured $11 \mathrm{~cm}$ in length and $0.7 \mathrm{~cm}$ in diameter and weighed (in air) $4.6 \mathrm{~g}$. I did not conduct a rigorous test of a possible effect of the glow stick on the crabs' behavior. However, field and laboratory observations of crabs marked with glow sticks indicated that they seemed to move normally and were able to crush and consume clams.

One marked crab (size range 110.0-140.0 mm CW $[$ mean $\pm 1 \mathrm{sE}=124.8 \pm 1.89 \mathrm{~mm}], n=29 \mathrm{crabs}$ ) was released in each enclosure and was allowed to acclimate for $\geq 1 \mathrm{~h}$ before the start of the observations. Two observers stood $\approx 2 \mathrm{~m}$ away from the enclosures, each monitoring the crabs in two to three enclosures. Every 2 min the position of each crab (i.e., of the red glow visible in the water) was marked on a map representing each enclosure. The activity of each crab (whether it was standing still or it was moving) was also recorded. Crabs that did not move for the whole observation period were excluded from the analyses. Because tidal phase was likely to affect the crabs use of intertidal habitats, half of the observation sessions were conducted on rising tides (19 October 1993, 13 June and 13 July 1994) and half on falling tides (27 October 1993, 21 June and 6 July 1994). Observations lasted between 2.5 and $3 \mathrm{~h}$ on each date, for a total of 75-90 records/crab. Water depth was measured every $30 \mathrm{~min}$ at a reference point outside the enclosures.

Possible differences in the use of salt marsh and sand flat habitats by individual crabs on rising and falling tides were tested for significance with a one-way ANOVA, with tidal phase (rising or falling tide) as a fixed factor and date (October, June, or July) as the blocking factor. The dependent variable in the ANOVA was the proportion of time spent by each crab in the vegetated portion of the enclosure. One-way ANOVA was also performed on the proportion of time spent moving to 

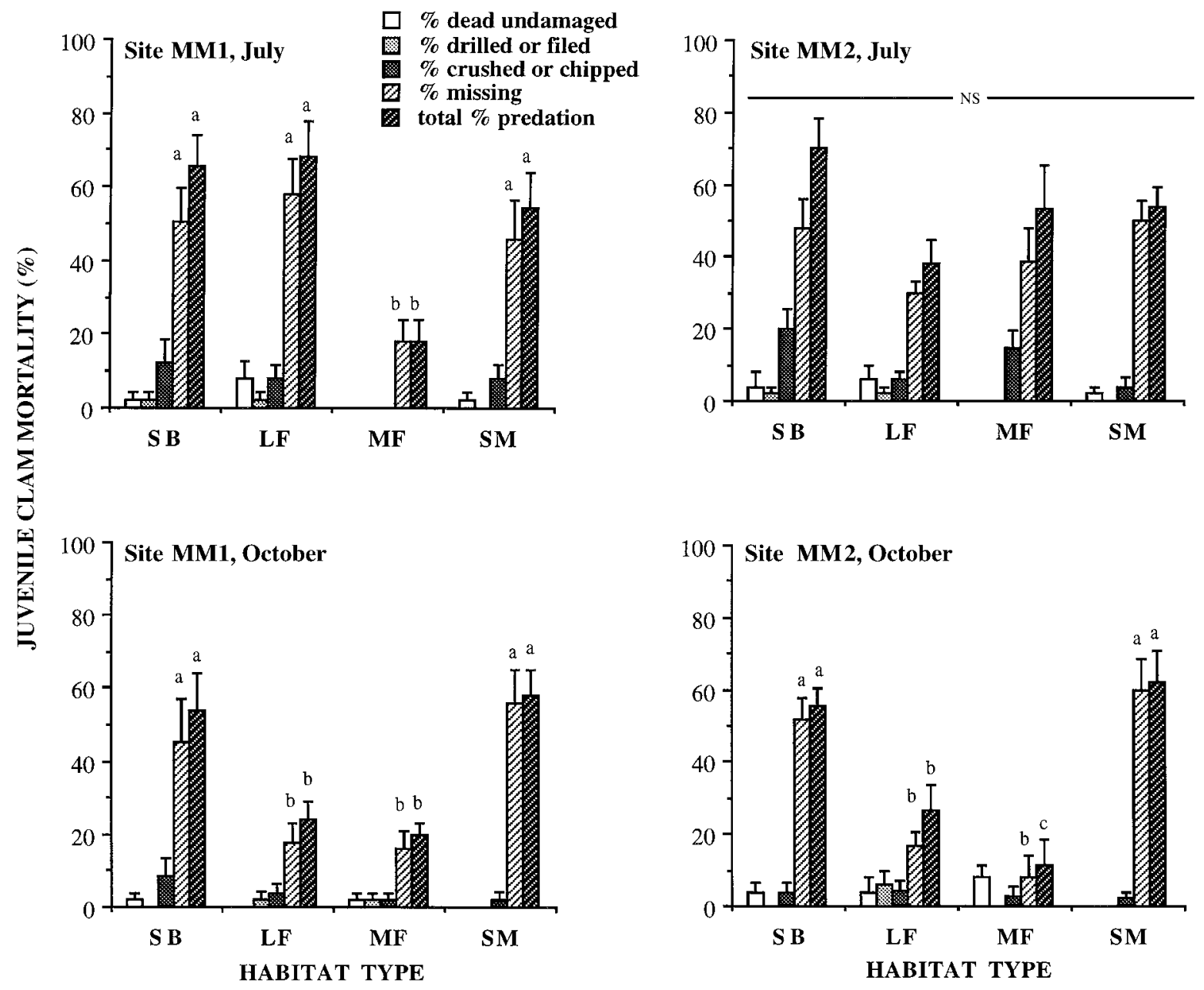

FIG. 3. Patterns of mortality of tethered hard clams in different habitat types ( $\mathrm{SB}=$ subtidal sand bottoms, LF $=$ lowintertidal flats, $\mathrm{MF}=$ mid-intertidal flats, and $\mathrm{SM}=$ intertidal salt marsh edges), at different seasons (summer and fall), and at two separate sites (sites MM1 and MM2). Bars show means and 1 SE $(n=5$ deployed strings of clams; see Methods: Mortality patterns of juvenile hard clams). Bars marked with different letters are significantly different at $\alpha=0.05$ (SNK). Separate SNK tests were performed for the different categories of clam losses, when ANOVA results indicated a significant difference among treatment combinations. Mortality of clams with undamaged shells was attributed to stress, disease, or parasitism; mortality of clams with drilled or filed shells was attributed to predation by gastropods; mortality of clams with crushed or chipped shells was attributed to predation by crabs. I assumed that missing clams had been carried off by predators. Total percentage predation of deployed clams was calculated as the sum of the percentage of clams missing and the percentage of clams dead with predation marks on their shells (see Methods: Mortality patterns ....).

compare activity levels between tidal phases and among dates. All crabs spent a large proportion of their time close to the enclosure edges. The proportion of time spent away from the edges was compared between tidal phases and dates to test whether this artifact of confinement changed its effect on the crabs' behavior depending on external conditions. Arcsine transformation was applied to all proportions before ANOVA. Cochran's tests indicated that, following arcsine transformation of data, variances were homogeneous for all analyses.

Based on the results of the field enclosure experiments, individual crabs were expected to spend more time within the vegetated habitat. This hypothesis was tested with a one-group $t$ test comparing the observed proportions of time spent in the vegetated habitat with the value of 0.5 , expected in the case that crabs did not exhibit any habitat preference. Because ANOVA indicated that the proportion of time that crabs spent in the salt marsh habitat differed significantly between rising and falling tides (see Results: Use of vegetated and unvegetated habitats ...), separate $t$ tests were conducted on data for each tidal phase.

\section{RESUlts}

\section{Mortality patterns of juvenile hard clams}

Predation accounted for most of the clam losses in the tethering experiments. After $1 \mathrm{wk}$, between $11.4 \%$ 


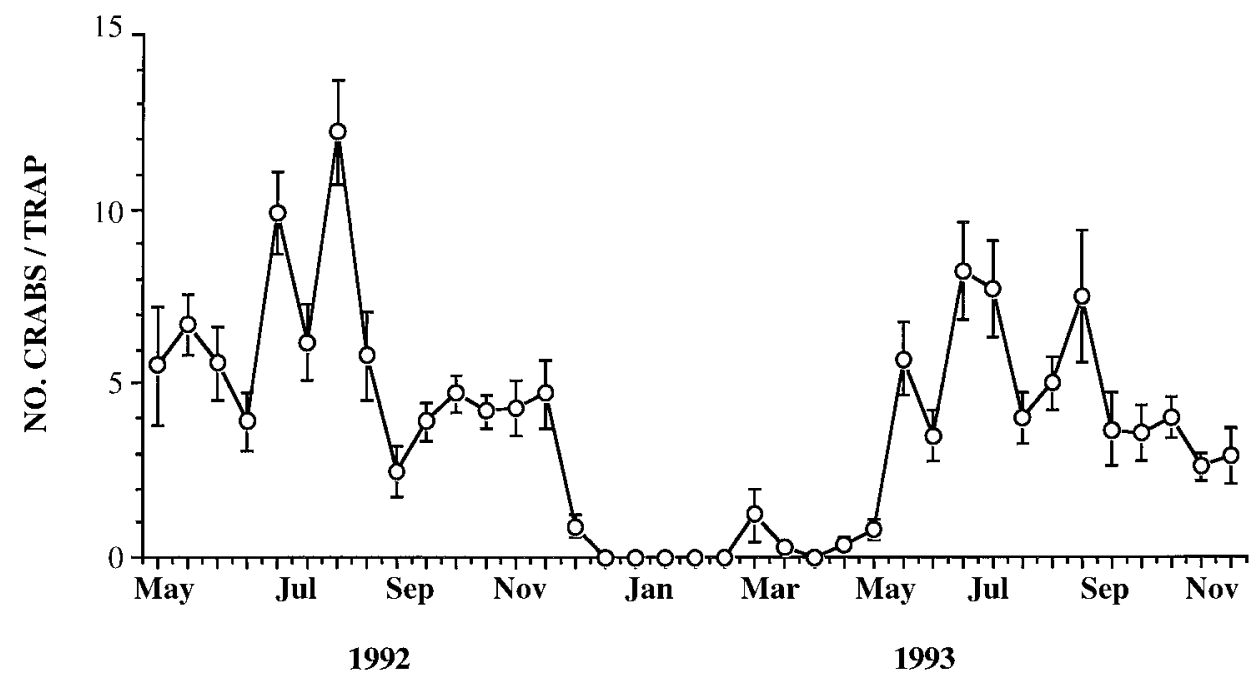

FIG. 4. Seasonal patterns of abundance of subadult and adult blue crabs (larger than $\approx 80 \mathrm{~mm}$ in carapace width) in the study area. Each data point is the average number of crabs $( \pm 1 \mathrm{SE})$ in 8-10 traps. Traps were deployed twice a month in the subtidal sand bottom habitat at both field sites.

and $70.0 \%$ of the clams, depending on site, habitat type, and season, were lost due to predation (Fig. 3). The majority of clam losses were due to missing clams (Fig. 3). I assumed that missing clams had been carried away by predators because tethers prevented clams from migrating from their initial location. Patterns in the percentage of clams missing and in total percentage predation among the four habitat types varied with site and season (significant site $\times$ habitat $\times$ season interactions; Table 2). In the summer, both the percentage of clams missing and total percentage predation were similar among the four habitats with the exception of the mid-intertidal sand flat at site MM1, where clam losses were significantly lower than in the other habitats (Fig. 3a). In the fall, percentage of clams missing and total percentage predation were significantly lower in the intertidal sand flats than in the subtidal sand

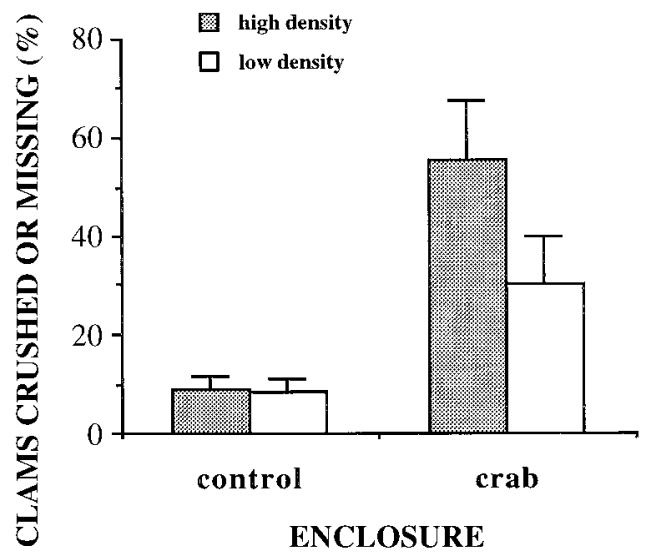

FIG. 5. Percentage of clams missing or crushed by individual blue crabs at patches of different densities (50 or 10 clams $/ \mathrm{m}^{2}$ ). Bars show means (and $1 \mathrm{SE}$ ) from seven replicate trials. bottoms or the intertidal salt marsh edges (Fig. 3b). At both sites, there was a trend for total percentage predation to decrease with increasing tidal elevation of the sand flats. This trend was significant at site MM2 but not at site MM1, where total percentage predation did not significantly differ between the two intertidal sand flats (Fig. 3b).

Of the clams that were found dead with predation marks on their shells, chipped or crushed clams were about six times more frequent than drilled or filed ones (crushed or chipped: mean $\pm 1 \mathrm{SE}=6.4 \pm 1.0 \%$; drilled or filed: $1.1 \pm 0.4 \% ; n=80$ strings of clams ). Based on these proportions, predation by crabs on juvenile hard clams appears to have been more intense than predation by gastropods. The percentage of clams with crushed or chipped shells, those probably preyed upon by crabs, was significantly greater in summer than fall (Table 2 and SNK test). In both seasons, \% crushed or chipped clams were not significantly different among habitats (Table 2 and Fig. 3). Proportions of dead clams with drilled or filed valves, those preyed upon by gastropods, differed significantly among habitats (Table 2 ). The percentage of dead clams with drilled or filed shells tended to be greater in the low intertidal flats than in the other habitats (Fig. 3). Moreover, this category of predation was never found in the salt marsh habitat (Fig. 3), indicating that predation by gastropods was not a significant source of mortality for juvenile clams in this habitat type. However, none of these trends were significant at $\alpha=0.05$ in post hoc comparisons of means conducted with the SNK test. Only $2.8 \pm 0.7 \%$ of the clams deployed in the field $(n=80$ strings) were found dead with no predation marks on their shells. Patterns in dead clams with undamaged shells varied with habitat and season (Table 2 and Fig. 3 ). Mortality attributed to stress was highest in the low- 
TABLE 2. Results of three-way ANOVAs comparing proportional losses of tethered juvenile hard clams (Mercenaria mercenaria) in different habitat types (subtidal sand bottoms, low-intertidal flats, mid-intertidal flats, and intertidal salt marsh edges) at different times of the year (summer and fall) and at two separate sites (site MM1 and MM2) (see Fig. 3).

\begin{tabular}{|c|c|c|c|c|c|c|c|c|c|c|}
\hline \multirow{3}{*}{$\begin{array}{c}\text { Source of } \\
\text { variation }\end{array}$} & \multirow[b]{3}{*}{ df } & \multicolumn{9}{|c|}{ Percentage of clams } \\
\hline & & \multicolumn{3}{|c|}{ Dead undamaged } & \multicolumn{3}{|c|}{ Drilled or filed } & \multicolumn{3}{|c|}{ Crushed or chipped } \\
\hline & & MS & $F$ & $P$ & MS & $F$ & $P$ & MS & $F$ & $P$ \\
\hline Site $(\mathrm{S})$ & 1 & 0.03 & 1.36 & 0.25 & $2.0 \times 10^{-4}$ & 0.02 & 0.89 & 0.03 & 0.86 & 0.36 \\
\hline Habitat $(\mathrm{H})$ & 3 & 0.02 & 0.89 & 0.45 & 0.03 & 2.70 & 0.05 & 0.08 & 2.12 & 0.11 \\
\hline Season (Se) & 1 & 0.001 & 0.03 & 0.85 & $3.1 \times 10^{-4}$ & 0.03 & 0.87 & 0.29 & 7.81 & 0.01 \\
\hline $\mathrm{S} \times \mathrm{H}$ & 3 & 0.006 & 0.24 & 0.87 & 0.005 & 0.46 & 0.71 & 0.05 & 1.38 & 0.26 \\
\hline $\mathrm{S} \times \mathrm{Se}$ & 1 & 0.03 & 1.36 & 0.25 & $2.0 \times 10^{-4}$ & 0.02 & 0.89 & 0.05 & 1.48 & 0.23 \\
\hline $\mathrm{H} \times \mathrm{Se}$ & 3 & 0.07 & 2.91 & 0.04 & 0.01 & 1.13 & 0.34 & 0.01 & 0.31 & 0.82 \\
\hline $\mathrm{S} \times \mathrm{H} \times \mathrm{Se}$ & 3 & 0.007 & 0.30 & 0.83 & 0.005 & 0.46 & 0.71 & 0.05 & 1.36 & 0.26 \\
\hline Residual & 64 & 0.02 & & & 0.01 & & & 0.04 & & \\
\hline
\end{tabular}

Notes: The dependent variables in the ANOVAs were the percentage of dead clams with no predation marks on their shells (dead undamaged), with marks attributed to predatory gastropods (drilled or filed), with marks attributed to crabs (crushed or chipped), missing, and preyed upon (total percentage predation). Total percentage predation was the sum of the clams missing or dead with predation marks on their shells.

intertidal flats in summer and in the mid-intertidal flats in fall, although these differences were not significant at $\alpha=0.05$ in SNK post hoc comparisons.

Handling associated with tethering tended to increase clam mortality inside the control cages. Mortality of tethered clams was greater than mortality of untethered clams (tethered clams: mean $\pm 1 \mathrm{SE}=8.6$ $\pm 3.1 \%$; untethered clams: $3.5 \pm 2.4 \% ; n=8$ cages), but this difference was not statistically significant (tethering-treatment effect: $F_{1,8}=2.94, P=0.12$ ). Clam mortality in the control cages was significantly greater in fall than summer (season effect: $F_{1,8}=9.49, P=$ $0.01)$. There was no significant effect of site and of all interaction terms on clam mortality inside the control cages $(P=0.33-0.97)$. A small proportion of the tethered clams came off the tethers: only 3 clams, out of a total of 80 tethered clams enclosed in the control cages, were found untethered after $1 \mathrm{wk}$.

\section{Seasonal patterns of blue crab abundance}

Abundances of adult blue crabs in the study area peaked during the summer months in 1992 and 1993 (Fig. 4). Maximum abundances were observed in July and August. Abundances declined in the fall, dropped to zero in the winter months (December-March) and increased in the spring. Based on these catch data, crab abundances were 1.5-3.0 times greater in the summer than in the fall and spring. Average blue crab abundance was 2.4 times greater in July 1993 than in October 1993, at the times when the tethering experiments were carried out.

\section{Effect of prey density}

When given a choice between prey patches of different densities, blue crabs ate proportionally more clams in high-density than in low-density prey patches (Fig. 5). Results of trials carried out on different dates were pooled after a preliminary analysis showed that there was no significant effect of date, the blocking factor in the ANOVA, on proportional mortality of clams at patches of different clam density $(P=0.61)$. The difference between the proportions of crushed or missing clams at the high- and low-density patches was significantly greater in the predator treatment than in the control treatment $(t=2.46$, df $=6, P=0.05)$. The total number of clams crushed or missing in the enclosures where a crab was added was significantly greater than in the control enclosures where no crabs were added $(t=3.44$, df $=6, P=0.01)$, indicating that the addition of crabs significantly increased clam losses in the enclosures.

\section{Effects of habitat structural complexity and crab size}

Both large and small blue crabs consumed more clams in the vegetated (salt marsh) than in the unvegetated (sand flat) portion of enclosures containing equal amounts of each habitat type (Fig. 6). Results of trials conducted on different dates were pooled and reanalyzed after a preliminary ANOVA showed that there was no significant effect of date $(P=0.48)$. Differences between the numbers of clams crushed or missing in the salt marsh and in the sand flat patches varied significantly among control enclosures, enclosures containing one small crab and enclosures containing one large crab $\left(F_{2,27}=21.09, P=0.0001\right)$. There was no significant difference between small and large crabs in their relative predation rates on clams located in the vegetated and unvegetated prey patches but both predator treatments differed significantly from the control treatment with no crabs (Games-Howell post hoc test).

The total numbers of clams crushed or missing from enclosures were significantly different among the three treatments $\left(F_{2,27}=8.1, P=0.002\right)$. Total clam losses were significantly greater in enclosures containing one crab than in the control enclosures with no crabs, whereas large and small crabs consumed similar numbers of clams (Tukey-Kramer post hoc test). 
TABLE 2. Continued.

\begin{tabular}{|c|c|c|c|c|c|}
\hline \multicolumn{3}{|c|}{ Percentage of clams } & \multirow{2}{*}{\multicolumn{3}{|c|}{$\begin{array}{l}\text { Total percentage } \\
\text { predation }\end{array}$}} \\
\hline \multicolumn{3}{|c|}{ Missing } & & & \\
\hline MS & $F$ & $P$ & MS & $F$ & $P$ \\
\hline 0.001 & 0.03 & 0.87 & $3.1 \times 10^{-5}$ & 0.001 & 0.98 \\
\hline 0.75 & 16.68 & 0.0001 & 0.80 & 18.34 & 0.0001 \\
\hline 0.29 & 6.41 & 0.01 & 0.53 & 12.11 & 0.001 \\
\hline 0.04 & 0.93 & 0.43 & 0.06 & 1.29 & 0.28 \\
\hline $1.1 \times 10^{-4}$ & 0.002 & 0.96 & 0.02 & 0.55 & 0.46 \\
\hline 0.20 & 4.50 & 0.01 & 0.13 & 3.08 & 0.03 \\
\hline 0.13 & 2.88 & 0.04 & 0.23 & 5.22 & 0.003 \\
\hline 0.05 & & & 0.04 & & \\
\hline
\end{tabular}

\section{Effects of habitat structural complexity and crab density}

The effects of crab density on proportional clam losses in vegetated and unvegetated habitats varied depending on clam density in the two habitat types. When clam density was 10 times greater in the salt marsh (100 individuals $/ \mathrm{m}^{2}$ ) than in the sand flat (10 individuals $/ \mathrm{m}^{2}$ ) portion of the enclosures, single crabs consumed proportionally more clams in the salt marsh than in the sand flat (Fig. 7a). However, at intermediate (3 crabs/enclosure) and high (6 crabs/enclosure) crab densities, crabs consumed similar proportions of clams in the two habitats (Fig. 7a). The difference in the proportion of missing or crushed clams between the two patches was significantly greater in the treatment where only one crab was added to the enclosures than in either of the other predator treatments with intermediate and high crab densities or in the control treatment with no crabs, with no significant differences among these $\left(F_{3,24}\right.$ $=6.53, P=0.002$, and Games-Howell post hoc test)

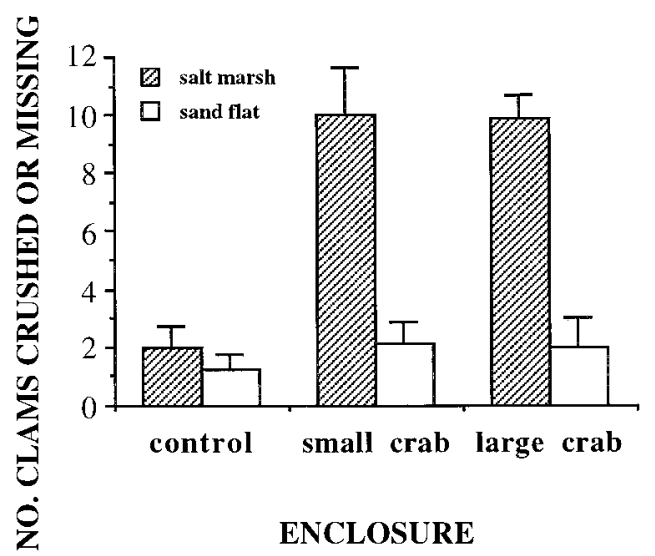

FIG. 6. Number of clams missing or crushed by individual crabs belonging to two different size classes (102.6-117.0 and 127.4-140.0 $\mathrm{mm}$ carapace width) at vegetated (salt marsh) and unvegetated (sand flat) prey patches. Bars represent averages (and 1 SE) of 9-12 trials. Differences between predation rates in the salt marsh and in the sand flat habitat were not significantly different between small and large crabs (Games-Howell post hoc test)
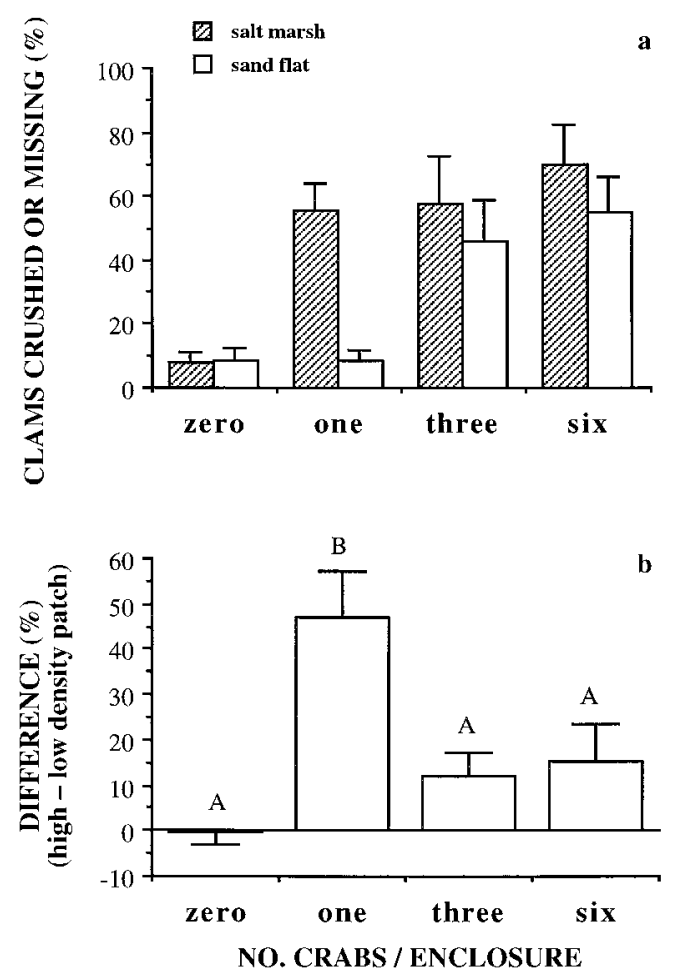

FIG. 7. (a) Percentage of crushed or missing clams deployed at high density $\left(100 \mathrm{clams} / \mathrm{m}^{2}\right)$ in the salt marsh and at low density $\left(10 \mathrm{clams} / \mathrm{m}^{2}\right)$ in the sand flat habitat and (b) differences between percentages of crushed or missing clams at the high- and low-density prey patches. Bars represent means (and $1 \mathrm{SE}$ ) of 6-8 trials. Bars marked with different letters are significantly different at $\alpha=0.05$ (Games-Howell post hoc test).

(Fig. 7b). The total number of clams crushed or missing differed significantly among treatments $\left(F_{3,24}=5.55, P\right.$ $=0.005)$. Clam losses were significantly greater in the predator treatments than in the control (Tukey-Kramer post hoc test). Although there was a trend for the total number of clams consumed in each enclosure to increase with increasing crab density, this trend was not significant at $\alpha=0.05$ (Tukey-Kramer post hoc test).

When clam distribution was reversed and clams were deployed at densities 10 times greater in the sand flat than in the salt marsh, proportional clam losses were similar between the two habitats at all crab densities (Fig. 8a). Differences between clam losses in the salt marsh and sand flat habitats did not vary significantly among treatments $\left(F_{3,21}=0.21, P=0.89\right)$ (Fig. 8b). The total number of clams crushed or missing was significantly different among treatments $\left(F_{3,9}=11.61, P\right.$ $=0.002$ ). Total numbers of clams crushed or missing in the predator treatments were significantly greater than in the control treatment and increased with increasing crab densities (Games-Howell post hoc test). Total numbers of clams consumed in the high-crab density treatment were significantly greater than in the lowdensity one. At intermediate crab densities, the total 
TABLE 3. Effect of risk of predation on crabs by large birds on the amount of predation by blue crabs (Callinectes sapidus) on clams (Mercenaria mercenaria) at vegetated and unvegetated prey patches in the soft sediments of Back Sound, North Carolina (see Fig. 10).

\begin{tabular}{|c|c|c|c|c|c|c|c|}
\hline \multirow{2}{*}{$\begin{array}{l}\text { Source of } \\
\text { variation }\end{array}$} & \multirow[b]{2}{*}{ df } & \multicolumn{3}{|c|}{$\begin{array}{c}\text { Difference in number } \\
\text { of crushed or missing clams }\end{array}$} & \multicolumn{3}{|c|}{$\begin{array}{c}\text { Total number of } \\
\text { crushed or missing clams }\end{array}$} \\
\hline & & MS & $F$ & $P$ & MS & $F$ & $P$ \\
\hline Bird density & 1 & 204.18 & 8.35 & 0.006 & 0.74 & 0.01 & 0.92 \\
\hline Crab density & 2 & 35.20 & 1.44 & 0.25 & 2377.48 & 30.67 & 0.001 \\
\hline Interaction & 2 & 37.96 & 1.55 & 0.23 & 1.28 & 0.02 & 0.98 \\
\hline Residual & 37 & 24.46 & & & 77.51 & & \\
\hline
\end{tabular}

Notes: The dependent variable in the first ANOVA is the difference between the number of crushed or missing clams in the salt marsh and the sand flat patches. The dependent variable in the second ANOVA is the total number of clams crushed or missing in each enclosure.

number of clams consumed was intermediate between the high- and low- crab density treatments and it was not significantly different from either one (GamesHowell post hoc test). Results of trials conducted on different dates were not pooled for ANOVA because the effect of date on the total number of clams crushed or missing in each enclosure, though not significant, had a probability $<0.25(P=0.12)$. Therefore date was left as a blocking factor in the ANOVA.
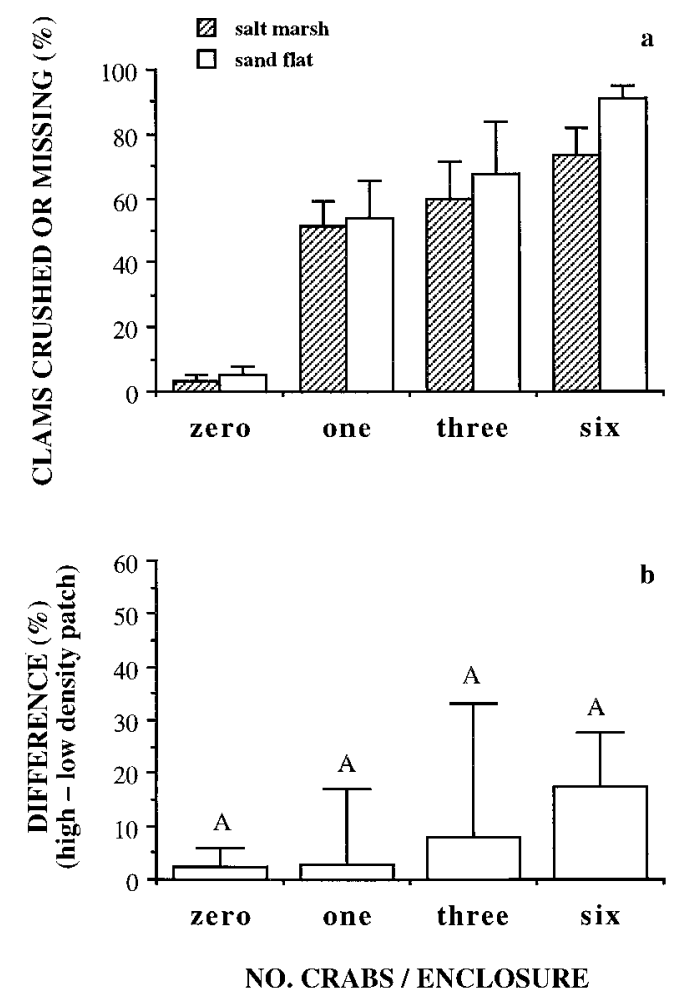

FIG. 8. (a) Percentage of deployed clams crushed or missing at high density $\left(100 \mathrm{clams} / \mathrm{m}^{2}\right)$ in the sand flat and at low density $\left(10 \mathrm{clams} / \mathrm{m}^{2}\right)$ in the salt marsh habitat and (b) differences between percentage of deployed clams crushed or missing at the high- and low-density prey patches. Bars represent means (and $1 \mathrm{SE}$ ) of 6-7 trials. There were no significant differences at $\alpha=0.05$ (Games-Howell post hoc test)

\section{Effects of predation risk and crab density}

The scare-away bird line and steel stakes effectively reduced bird densities in and around the enclosures. Observations conducted on two dates showed that birds only occasionally visited the bird exclosures, while they were always present on and around the control enclosures (Fig. 9). Terns comprised the vast majority of birds that visited the enclosures ( 89.6 and $99.3 \%$ on 18 and 25 October, respectively). All other birds were herring and ring-billed gulls. Birds did not directly consume any crabs during this experiment.

Exclusion of birds from the enclosures had a sig-

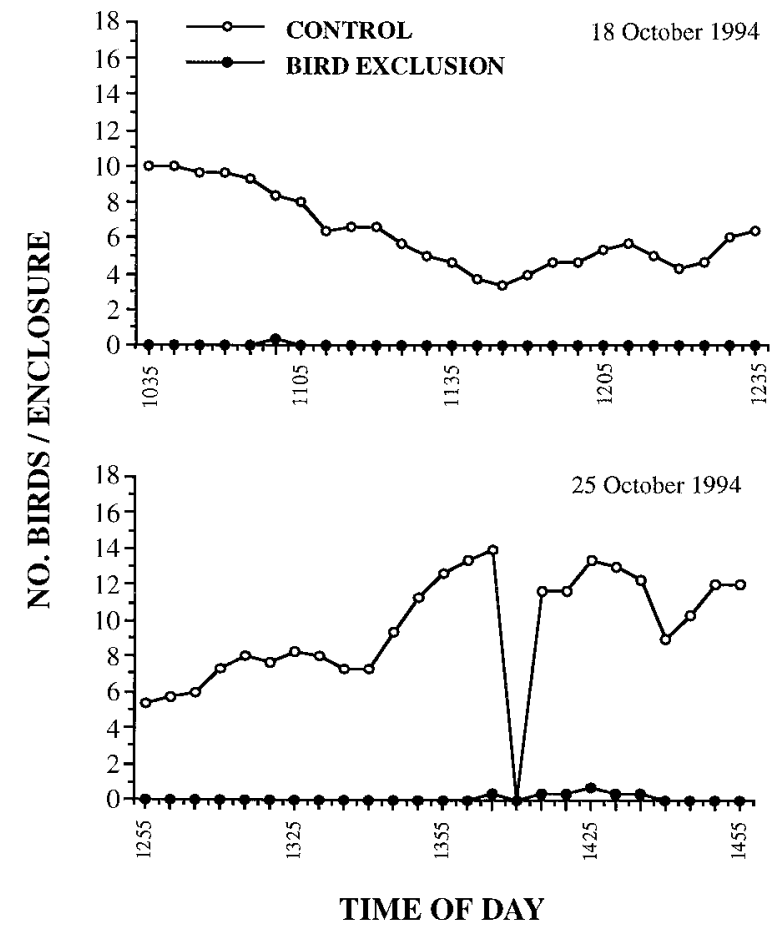

FIG. 9. Average number of birds counted on and around enclosures at 5-min intervals, on two occasions. On each date, birds were excluded from three enclosures (BIRD EXCLUSION), while three enclosures served as controls (CONTROL). Data points are average numbers of birds counted on three enclosures. 

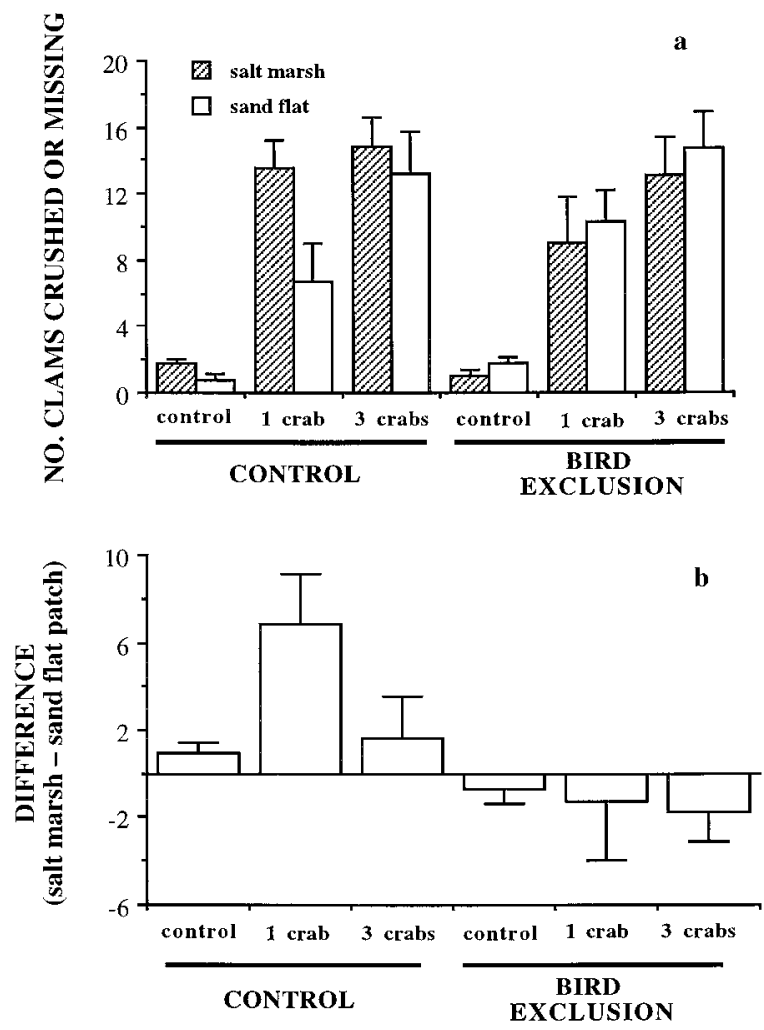

FIG. 10. (a) Number of deployed clams crushed or missing at patches of equal clam density (20 individuals $\left./ \mathrm{m}^{2}\right)$ in vegetated (salt marsh) and unvegetated (sand flat) habitats in treatments with zero, one, and three crabs per enclosure. Risk of predation for the crabs was manipulated by excluding birds from half of the enclosures (BIRD EXCLUSION) while leaving the remaining enclosures unmanipulated (CONTROL). (b) Differences in the number of clams crushed or missing in vegetated vs. unvegetated habitats. Bars represent means (and $1 \mathrm{SE}$ ) of $6-8$ trials.

nificant effect on the patterns of predation by crabs on clams in vegetated and unvegetated habitats (Table 3 ). More clams were missing or had been crushed in the salt marsh than in the sand flat in the presence of birds, whereas similar clam losses were observed in the two habitat types when birds were excluded (Fig. 10). This was true at all crab densities, as indicated by the non- significant ANOVA interaction between the effects of the bird-density and crab-density treatments on the differences between clam losses in the two habitats (Table 3).

Manipulation of crab density had a significant effect on the total number of clams crushed or missing in the enclosures, while exclusion of birds had no significant effect on total clam losses (Table 3). Significantly more clams were crushed or missing in treatments with three crabs per enclosure than in those with only one crab per enclosure, and significantly more clams were crushed or missing in the one-crab treatments than in the controls (Tukey-Kramer post hoc test).

\section{Use of vegetated and unvegetated habitats by blue crabs}

At the beginning of the observations conducted on rising tides, water depths inside the enclosures ranged between 15.1 and $50.5 \mathrm{~cm}$ in the salt marsh and between 18 and $52.5 \mathrm{~cm}$ in the sand flat. By the end of the observation period, the water had reached a depth of $56.3-81.5 \mathrm{~cm}$ in the salt marsh and $62-83.5 \mathrm{~cm}$ in the sand flat. At the beginning of the observations conducted on falling tides, water depths ranged between 56.5 and $87.5 \mathrm{~cm}$ in the salt marsh, between 68 and $89.5 \mathrm{~cm}$ in the sand flat. Water depths had dropped to $15.0-27.1 \mathrm{~cm}$ in the salt marsh and $15.0-36 \mathrm{~cm}$ in the sand flat at the end of the observation period.

Tidal phase had a significant effect on habitat use by blue crabs (Table 4). Crabs spent similar proportions of time in the two habitat types on rising tides, while they spent significantly more time in the sand flat than in the marsh habitat on falling tides (Fig. 11a). Date had no significant effect on habitat use by blue crabs (Table 4). On rising tides, crabs spent $55.1 \pm 7.8 \%$ of their time in the salt marsh portion of the enclosures (mean $\pm 1 \mathrm{SE}, n=14$ trials) (Fig. 11a). This value is not significantly different from $50 \%$, the expected habitat use if the crabs showed no habitat preference $(t=$ 0.65 , df $=13, P=0.53)$. On falling tides, crabs spent $29.0 \pm 5.4 \%$ of their time in the marsh habitat $(n=$ 15 trials) (Fig. 11a). This value is significantly $<50 \%$ $(t=3.91$, df $=14, P=0.002)$.

TABLE 4. Use of salt marsh and intertidal flat habitats by individual blue crabs (Callinectes sapidus) in soft sediments of Back Sound, North Carolina.

\begin{tabular}{|c|c|c|c|c|c|c|c|c|c|c|c|c|c|c|}
\hline \multirow{3}{*}{$\begin{array}{l}\text { Source of } \\
\text { variation }\end{array}$} & \multirow[b]{3}{*}{ df } & \multicolumn{13}{|c|}{ Percentage of observations } \\
\hline & & \multicolumn{3}{|c|}{ In salt marsh } & \multicolumn{3}{|c|}{ Moving } & \multicolumn{3}{|c|}{ Away from edges } & \multicolumn{4}{|c|}{$\begin{array}{c}\text { In salt marsh } \\
\text { (away from edges) }\end{array}$} \\
\hline & & MS & $F$ & $P$ & MS & $F$ & $P$ & MS & $F$ & $P$ & $\mathrm{df}$ & MS & $F$ & $P$ \\
\hline Tidal phase & 1 & 0.77 & 7.46 & 0.01 & 0.63 & 4.56 & 0.04 & 0.13 & 1.52 & 0.23 & 1 & 0.92 & 5.72 & 0.03 \\
\hline Date & 2 & 0.21 & 2.01 & 0.15 & 0.23 & 1.65 & 0.21 & 0.10 & 1.20 & 0.32 & 2 & 0.16 & 0.97 & 0.40 \\
\hline Residual & 25 & 0.10 & & & 0.14 & & & 0.08 & & & 20 & 0.16 & & \\
\hline
\end{tabular}

Notes: Separate ANOVAs were performed on the proportion of observations when crabs were in the salt marsh (Fig. 11a), on the proportion of observations when crabs were moving, on the proportion of observations when crabs were away from the enclosure edges, and on the proportion of observations in the salt marsh over the number of observations away from the edges (Fig. 11b). Tidal phase was a fixed factor in the ANOVA, while date was the blocking factor. 

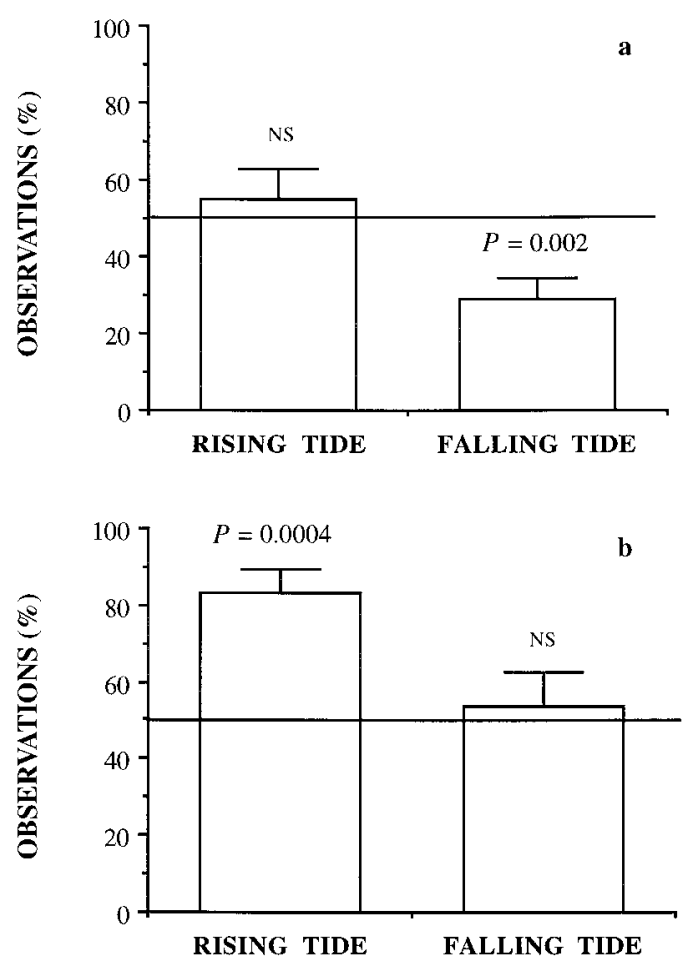

FIG. 11. (a) Percentage of observations of individual blue crabs in the salt marsh habitat and (b) percentage of observations of crabs in the salt marsh, after observations near the enclosure walls had been excluded. Crabs were presented with similar surface areas of a salt marsh and adjacent sand flat habitats $\left(\approx 12.8-15 \mathrm{~m}^{2}\right.$ each $)$. Observations were conducted on three rising and three falling tides. Bars represent averages (and $1 \mathrm{SE}$ ) of 11-15 trials. The horizontal line in the graphs represents the $50 \%$ value expected in the case that crabs did not exhibit a preference for one habitat type. $P$-values of onegroup $t$ tests comparing observed and expected proportions are reported above each bar (see Results: Use of vegetated and unvegetated....).

Crabs were more active on falling tides (they were moving on $63.7 \pm 7.9 \%$ of the observations (mean \pm $1 \mathrm{sE}, n=15$ trials) than rising tides (44.4 $\pm 7.6 \%, n$ $=14$ trials) on all dates (Table 4). Regardless of date or tidal phase (Table 4), crabs spent most of their time close to the edges of the enclosures, either buried against the fences or walking up and down the enclosure edges. Crabs spent $16 \pm 3.7 \%$ of their time away from the enclosure edges $(n=29$ trials $)$. Five out of the 29 crabs observed spent all their time along the enclosure edges. Confinement seemed to affect the crabs' use of the space available to them but the effects of this experimental artifact did not change with date and tidal phase.

When only the time spent away from the enclosure edges was considered, the proportion of time spent in the salt marsh habitat was also significantly greater at rising than at falling tides on all dates (Table 4). On rising tides, $83.0 \pm 6.4 \%$ of the time spent away from the edges was spent in the salt marsh habitat (mean \pm $1 \mathrm{SE}, n=11$ trials) (Fig. 11b). This value is signifi- cantly $>50 \%(t=5.17$, df $=10, P=0.0004)$. On falling tides, $53.7 \pm 9.0 \%$ of the time spent away from the edges was spent in the marsh habitat ( $n=13$ trials) (Fig. 11b). This value is not significantly different from $50 \%(t=0.41, \mathrm{df}=12, P=0.69)$.

\section{DISCUSSION}

Characteristics of the predatory behavior of individual blue crabs appeared to explain observed spatial and seasonal patterns of predation on tethered hard clams exposed to the natural predator assemblage in estuarine soft-sediment habitats. In the summer, tethered clams suffered similar predation mortality in all habitats (with the exception of one intertidal flat at one of the sites) (Fig. 3a). In the fall, clam predation mortality was lower in intertidal sand flats than in either subtidal sand bottoms or just inside the edge of intertidal salt marshes (Fig. 3b). A previous study (Micheli 1996) found that in the spring clam mortality patterns were similar to those observed in the fall in this study. These patterns could be explained by at least two alternative hypotheses: (1) different predator guilds caused clam mortality in different habitats and seasons, and/or (2) predation rates of individual predators varied in response to the external conditions found in different habitats and seasons. In this study, I focused on the second hypothesis because previous studies (Virnstein 1977, Hines et al. 1990, Peterson 1990, Eggleston et al. 1992) indicated that blue crabs are the main cause of mortality of infaunal bivalves in soft-bottom marine habitats of the eastern U.S. Blue crabs are thus likely candidates as keystone predators (Paine 1969) in this system. Variation in their predation rates and habitat use were expected to produce significant changes in the patterns of mortality of their prey.

Blue crabs modified their predation rates on infaunal clams under different conditions following qualitative predictions of foraging theory (Pyke 1984, Stephens and Krebs 1986). Crabs were expected to have greater feeding rates at patches where prey were more abundant and where risk of predation by higher order predators was lower (MacArthur and Pianka 1966, Charnov 1976, Milinski and Heller 1978, Sih 1980, Cerri and Fraser 1983, Gilliam and Fraser 1987, Holbrook and Schmitt 1988, Lima and Dill 1990, Fraser and Gilliam 1992). In manipulative experiments conducted in field enclosures, individual blue crabs consumed proportionally more prey at high-density prey patches than at lowdensity ones (Fig. 5). Individual crabs also consumed more prey (Fig. 6) and spent more time (Fig. 11) at vegetated than at unvegetated prey patches. Greater predation rates at vegetated than unvegetated prey patches were observed in crabs belonging to different size classes, although only fairly large crabs were considered in this study. These results may explain the greater predation rates on clams just inside the edge of intertidal salt marshes, compared to intertidal sand flats, observed in the fall tethering experiment (Fig. 
3b). Salt marsh habitats are characterized by high prey densities. Sampling of these habitats showed that the densities of blue crab prey, mainly benthic molluscs and crustaceans, in the study area were 10-30 times greater along the edge of intertidal salt marshes than in subtidal and intertidal sand flats (F. Micheli, unpublished data). Hard clams persisted at high densities along the edge of salt marshes despite the high predation rates observed because they had high recruitment and fast growth in this habitat (F. Micheli, unpublished data).

When prey were 10 times more abundant in the vegetated than in the unvegetated patch, individual crabs consumed proportionally more clams at the vegetated high-density patch than at the unvegetated low-density one (Fig. 7). However, when prey distribution was reversed, individual crabs consumed similar proportions of prey at the unvegetated high-density patch and at the vegetated low-density one (Fig. 8). These results suggest that crabs may leave low-density prey patches more readily when these are in unvegetated than in vegetated habitats. Results of the direct observation of the habitat use by individual crabs further supported this hypothesis. Observations conducted at different times of the year and at different tidal phases indicated that individual crabs spent overall more time in the vegetated habitat than expected by chance (Fig. 11b).

A possible explanation for the crabs' preference for the vegetated habitat is that emergent vegetation may protect the crabs from their visual predators, such as large birds and fishes. Emergent vegetation has been shown to reduce predation mortality of a variety of aquatic organisms (Coen et al. 1981, Heck and Thoman 1981, Crowder and Cooper 1982, Leber 1985). Crabs may spend a longer time at vegetated prey patches than expected based on prey availability alone because vegetated habitats are safer than unvegetated ones. This hypothesis was supported by the result that risk of predation by birds significantly increased the feeding rates of blue crabs in vegetated habitats. When the field enclosures were visited by birds, more clams were preyed upon in the salt marsh habitat than in the sand flat habitat, whereas similar predation rates were observed in the two habitats when birds had been excluded from the enclosures (Fig. 10). The hypothesis that direct predation by birds on clams may explain these results can be ruled out because mortality of clams in the controls (with no crabs added) was not significantly different between treatments with and without birds (Table 3 ). In addition, birds were never seen feeding at the clam patches within the enclosures. The significant effect of the bird-density manipulation on clam mortality patterns was not caused by direct predation of birds on crabs because no crab mortality was observed in this experiment. Therefore, the effect of birds on the patterns of clam mortality in the two habitat types must be in the form of an interaction modification (Wootton 1993), where the presence of birds affected the outcome of the predator-prey interaction between crabs and clams without changing the crab densities.

Bird abundances on and around the enclosures, during the experiments, may have been greater than natural ones. The wooden posts supporting the enclosure walls seemed to attract birds, particularly terns, by providing perches. Nevertheless, this experiment showed that blue crabs were able to perceive risk of predation and to modify their foraging behavior accordingly. Birds that visited the enclosures during the experiment were mostly terns, which have not been reported to feed on blue crabs. Larger birds, such as gulls and herons, are more likely potential predators of blue crabs (Prescott 1990; T. G. Wolcott, personal communication). However, blue crabs may have perceived any large bird as a potential threat and thus responded to their presence, regardless of the bird species.

In the study area, abundances of the large birds reported to prey upon blue crabs such as herring (Larus argentatus) and ring-billed gulls (L. delawarensis) begin to increase in October, when these species arrive to overwinter onshore (Peterson 1990, Prescott 1990). Tides in the study area also tend to be lower in the fall than in the summer (Peterson 1990), so that water depth in intertidal habitats tended to be lower in the fall than in the summer months. Thus, blue crabs were at greater risk of predation from birds in the fall than in the summer. A proportionally greater use by blue crabs of safer habitats, such as vegetated or deeper bottoms, compared with less safe habitats, such as intertidal flats, may be expected in the fall compared to the summer. A preference for safer habitats by blue crabs may thus explain the greater predation intensity on clams observed in subtidal sand bottoms and intertidal salt marshes than in intertidal flats in the fall tethering experiments.

Ideal free distribution models predict that groups of predators distribute themselves between patches of different prey densities in proportion to prey availability, and hence cause similar proportional mortality of prey at the different patches (Fretwell and Lucas 1970, Sutherland 1983). In agreement with this prediction, groups of crabs caused similar proportional mortality of clams between high- and low-density prey patches both when prey distribution in the enclosures mimicked the natural abundances of prey in intertidal salt marshes and in intertidal sand flats and when prey distribution was reversed (Figs. 7 and 8). One possible mechanism explaining this result is that interference with conspecifics may have forced crabs to disperse and forage in different habitat types. Dispersal of predators into less preferred habitats resulting from intraspecific interference has been reported in both terrestrial and aquatic predator-prey systems (Hassell 1971, Sih 1981, Eveleigh and Chant 1982, Ens and Goss-Custard 1984, Palumbi and Freed 1988). Alternatively, mechanisms other than direct interference with conspecifics may explain the effect of crab density on predation patterns 
of blue crab on clams in the enclosure experiments. In particular, exploitation competition may be the mechanism causing these patterns. Groups of crabs may deplete the high-density prey patch more quickly than individual crabs, thereby causing one or more crabs to leave that patch and start feeding at the low-density patch. Observations of blue crab behavior conducted in the laboratory (Mansour and Lipcius 1991) indicate that interference competition due to the crabs' aggressive behavior is the likely mechanism causing crabs to disperse in their environment when faced with conspecifics.

The observed effect of crab density on predation patterns on clams among vegetated and unvegetated habitats is likely to have been more important in the summer than in the fall because abundances of adult blue crabs in the study area were 1.5-3 times greater in the summer months (particularly July and August) than in the fall (late September through November) (Fig. 4). Blue crabs may have dispersed and fed in a greater variety of habitats in the summer, when their densities were the highest, than in the fall. Thus, dispersal of crabs to unvegetated habitats resulting from high crab densities may explain the lack of significant between-habitat differences in clam predation mortality observed in the tethering experiments in the summer.

In summary, enclosure experiments examining predation rates by individual blue crabs presented with different foraging situations indicated that prey availability in different habitat types and risk of predation are likely explanations for why crabs have greater predation rates on clams within salt marshes than in unvegetated habitats of similar tidal elevation. At high crab densities, crabs disperse and feed in both vegetated and unvegetated habitats.

These experiments established a link between behavioral ecology, foraging theory in particular, and community ecology in the study of predator-prey interactions in shallow marine habitats. Although foraging theory has been the object of considerable debate and criticism (Pierce and Ollason 1987), a plethora of field and laboratory studies have shown agreement between observed foraging behaviors and the predictions of models based on foraging theory (reviewed by Stephens and Krebs 1986). This study also showed that foraging theory yields correct qualitative predictions of the patterns of predation and habitat use by blue crabs. In particular, crabs appeared to balance the demands of increasing their energy intake by foraging where food was more abundant, and minimizing risk represented by large conspecifics and higher order predators such as large birds. By predicting what factors dictate foraging choices of individual crabs, foraging theory provided a framework for understanding the impact of crabs on the distribution and abundance of an economically important prey species (e.g., Peterson 1990). In this study, the foraging choices of predators appeared to explain the patterns of mortality of their prey. Such foraging choices were in turn affected by higher order predators in the community (birds). Thus, an investigation of blue crab predation patterns elucidated complex interactions between different trophic levels in this community. Patterns of mortality of benthic prey in this system were not only directly affected by epibenthic consumers but were also indirectly affected by higher order predators through modification of the predation patterns of an epibenthic predator.

The individual-based approach adopted in this study allowed for the identification of the variables that are likely to be most important in determining patterns of mortality of infaunal bivalves in this system. Despite the great variability in the physical characteristics of different estuarine habitats and in the species composition and size structure of the predator guilds foraging in these habitats (Hines et al. 1990), spatial and seasonal patterns of predation mortality of juvenile clams might be explained by the responses of one of their predators to relatively few variables, namely prey distribution, habitat structural complexity, crab density, and risk of predation by birds. This result could be produced by at least two distinct mechanisms: (1) different species and ontogenetic stages of predators respond in a similar way to changes in external conditions, or (2) large blue crabs are key predators in this system, and their impact on benthic prey overwhelms the effects of other predators. Studies of the relative importance of different species and ontogenetic stages of epibenthic predators and of the effects of external conditions on their feeding rates are needed to clarify the role of blue crabs as possible keystone predators in this system (Menge et al. 1994).

The consequences of intense predation on the structure of marine benthic communities are expected to differ between hard- and soft-bottom environments (Peterson 1979, Kvitek et al. 1992, Menge et al. 1994). In Paine's (1969) original definition, a keystone predator preferentially consumes and holds in check those species that would otherwise dominate the system. Such competitive dominants are a feature of most marine hard bottoms but are generally lacking in soft sediments (Peterson 1979). In soft sediments, high predation rates commonly result in decreases in abundance and changes in the size structure of prey populations rather than in changes in species diversity (Peterson 1979, Kvitek et al. 1992). Indirect effects of predation on soft-sediment communities have also been shown to occur through sediment disturbance (Woodin 1978, Oliver and Slattery 1985, Kvitek et al. 1992) and because of trophic interaction chains. In the salt marshes of the southeastern U.S., for example, the killifish Fundulus heteroclitus has been shown to decrease predation rates on benthic macrofauna by consuming shrimp, the intermediate predators in this system (Kneib 1988). In these examples, direct and indirect effects of predation on soft-sediment benthic communities did not 
produce species replacement or competitive dominance by one or few species. Blue crabs are voracious, opportunistic (Laughlin 1982, Hines et al. 1990, Fitz and Wiegert 1991), and highly mobile predators (Hines and Wolcott 1990), and they have been shown to have a significant impact on bivalve populations (Virnstein 1977, Hines et al. 1990, Peterson 1990, Eggleston et al. 1992). However, it is not known whether such intense predation can modify the structure of the benthic community through indirect and cascading effects analogous to those described in other systems (Paine 1966 Estes and Palmisano 1974, Estes et al. 1978, Duran and Castilla 1989, Schoener 1993, Wootton 1993, Menge et al. 1994). Thus, one cannot attribute the role of keystone predator to the blue crab at this time.

\section{Gradients of predation in intertidal soft-bottoms}

Experimental manipulations conducted on rocky shores have produced generalizations about processes that structure marine communities along gradients in physical rigor (Paine 1966, Dayton 1971, Connell 1972, 1975, Menge 1978a, b, 1983). Two generalizations about the impact of predators on intertidal communities are that (1) the intensity of predation decreases with increasing tidal elevation because marine predators are limited by tidal flooding high on the shore (Dayton 1971, Connell 1972, 1975, Menge 1978a, 1983); and that (2) the intensity of predation decreases with increasing structural complexity of the habitat, as prey can find refuges from predators in holes and crevices (Menge and Lubchenco 1981). The generality of these models and their applicability to other intertidal systems have been questioned (Underwood and Denley 1984, Peterson 1991). One of the main criticisms raised by both studies was that these models focus on the physical constraints to predation while disregarding other variables affecting predation rates, such as the behavior and mobility of predators. This study supports the importance of predators' behavior in determining their impact on prey populations in soft-sediment intertidal habitats. Responses of blue crabs to external conditions resulted in significant differences in the patterns of mortality of their prey between vegetated and unvegetated intertidal habitats.

Other mobile animals feeding in intertidal areas have been shown to maximize the time spent in the most profitable zones by modifying their behavior during the tidal cycle. In both rocky and sedimentary shores, gulls spend significantly more time foraging in the low-intertidal zone, where their preferred prey are found (Ambrose 1986, Irons et al. 1986). In the estuarine systems of the eastern U.S., killifish (Fundulus heteroclitus), aggregate in the salt marsh habitat at flooding tides, thereby maximizing the time spent at higher tidal elevations (Kneib 1984). In this study, blue crabs also modified their habitat use during the tidal cycle so that they spent more time in the vegetated habitat. In addition, crabs modified their predation rates within dif- ferent intertidal habitats in response to the abundance of conspecifics and of higher order predators (large birds). Because the abundances both of blue crabs and of avian predators varied with season, the crabs' predation rates in different habitats were expected to vary with season as well. Seasonal changes of predator behavior may add another source of variability to the patterns of predation in intertidal areas. These results indicate that investigations of the foraging behavior of key predators and of the consequences of such behavior for prey communities are needed to understand and make predictions about patterns of predation along environmental gradients.

\section{ACKNOWLEDGMENTS}

I wish to thank R. Black, L. B. Crowder, E. A. Irlandi, H. S. Lenihan, P. S. Levin, A. MacLachlan, C. H. Peterson, G. A. Skilleter, and H. C. Summerson for their comments and suggestions. J. F. Gilliam, M. E. Hay, E. A. Irlandi, H. S. Lenihan, C. H. Peterson, A. E. Stiven, J. Pinckney, T. G. Wolcott, and two anonymous reviewers improved drafts of this manuscript. The help of A. Beckwith, M. V. Chiarugi, E. Conclin, W. W. Ellington, W. L. Falls, A. S. Gallagher, A. R. Hall, J. T. Ham, A. N. Hendrix, L. Hillstrom, M. Klompas, H. S. Lenihan, N. A. McCall, G. McKinny, G. McQuilkin, S. Micheli, B. A. Orlando, J. Purifoy, G. M. Rullo, G. Safrit, and P. Wyrick with various aspects of the field and laboratory work is greatly appreciated. Financial support for this study was provided by a grant from the State Legislature of North Carolina (through the Cooperative Institute of Fisheries Oceanography) to C. H. Peterson, and a Fulbright scholarship for graduate studies in the United States, a Sigma-Xi Grantin-Aid, and a dissertation fellowship from the graduate school of UNC-CH to F. Micheli. This research was done in partial fulfillment of the requirements for a Ph.D. degree at the University of North Carolina at Chapel Hill.

\section{Literature Cited}

Ambrose, W. G., Jr. 1986. Estimate of removal rate of Nereis virens (Polychaeta: Nereidae) from an intertidal mud flat by gulls (Larus spp.). Marine Biology 90:243-247.

Arnold, W. S. 1984. The effects of prey size, predator size, and sediment composition on the rate of predation of the blue crab, Callinectes sapidus Rathbun, on the hard clam, Mercenaria mercenaria (Linné). Journal of Experimental Marine Biology and Ecology 80:207-219

Bernstein, C., A. Kalcenik, and J. R. Krebs. 1991. Individual decisions and the distribution of predators in a patchy environment. II. The influence of travel costs and structure of the environment. Journal of Animal Ecology 60:205225.

Blundon, J. A., and V. S. Kennedy. 1982. Refuges for infaunal bivalves from blue crab, Callinectes sapidus (Rathbun), predation in the Chesapeake Bay. Journal of Experimental Marine Biology and Ecology 65:67-81.

Castagna, M., and J. N. Krauter. 1985. Mercenaria culture using stone aggregate for predator protection. Proceedings of the National Shellfish Association 67:1-6.

Cerri, R. D., and D. F. Fraser. 1983. Predation and risk in foraging minnows: balancing conflicting demands. American Naturalist 121:552-561.

Charnov, E. L. 1976. Optimal foraging: the marginal value theorem. Theoretical Population Biology 9:129-136.

Coen, L. D., K. L. Heck, and L. G. Abele. 1981. Experiments on competition and predation among shrimps of seagrass meadows. Ecology 62:1484-1493

Connell, J. H. 1972. Community interactions on marine 
rocky intertidal shores. Annual Review of Ecology and Systematics 3:169-192.

. 1975. Some mechanisms producing structure in natural communities: a model and some evidence from field experiments. Pages 460-490 in M. L. Cody and J. M. Diamond, editors. Ecology and evolution of communities. Belknap, Cambridge, Massachusetts, USA.

Crowder, L. B., and W. E. Cooper. 1982. Habitat structural complexity and the interaction between bluegills and their prey. Ecology 63:1802-1813.

Day, R. W., and G. P. Quinn. 1989. Comparisons of treatments after an analysis of variance in ecology. Ecological Monographs 59:433-463.

Dayton, P. K. 1971. Competition, disturbance and community organization: the provision and subsequent utilization of space in a rocky intertidal community. Ecological Monographs 41:351-389.

DeAngelis, D. L., and L. J. Gross, editors. 1992. Individualbased models and approaches in ecology, populations, communities and ecosystems. Chapman and Hall, New YorkLondon, USA-UK.

Duran, L. R., and J. C. Castilla. 1989. Variation and persistence of the middle rocky intertidal community of central Chile, with and without human harvesting. Marine Biology 103:555-562.

Eggleston, D. B, R. N. Lipcius, and A. H. Hines. 1992. Density-dependent predation by blue crabs upon infaunal clam species with contrasting distribution and abundance patterns. Marine Ecology Progress Series 85:55-68.

Ens, B. J., and J. D. Goss-Custard. 1984. Interference among oyster catchers, Haematopus ostralegus, feeding on mussels, Mytilus edulis, in the Exe estuary. Journal of Animal Ecology 53:217-231.

Estes, J. A., and J. F. Palmisano. 1974. Sea otters: their role in structuring near shore communities. Science 185:10581060.

Estes, J. A., N. S. Smith, and J. F. Palmisano. 1978. Sea otter predation and community organization in the western Aleutian Islands, Alaska. Ecology 59:822-833.

Eveleigh, E. S., and D. A. Chant. 1982. Experimental studies on acarine predator-prey interactions: the effects of predator density on prey consumption, predator searching efficiency, and the functional response to prey density (Acarina: Phytoseiidae). Canadian Journal of Zoology 60:611629.

Fitz, H. C., and R. G. Wiegert. 1991. Utilization of the in tertidal zone of a salt marsh by the blue crab Callinectes sapidus: density, return frequency and feeding habits. Marine Ecology Progress Series 76:249-260.

Folk, R. L. 1980. Petrology of sedimentary rocks. Second edition. Hemphill, Austin, Texas, USA.

Fraser, D. F., and J. F. Gilliam. 1992. Nonlethal impacts of predator invasion: facultative suppression of growth and reproduction. Ecology 73:959-970.

Fretwell, S. D., and H. L. Lucas. 1970. On territorial behavior and other factors influencing habitat distribution in birds. I. Theoretical development. Acta Biotheoretica 19: $16-36$.

Gilliam, J. F., and D. F. Fraser. 1987. Habitat selection under predation hazard: test of a model with foraging minnows. Ecology 68:1856-1862.

Gilliam, J. F., D. F. Fraser, and A. M. Sabat. 1989. Strong effects of foraging minnows on a stream benthic invertebrate community. Ecology 70:445-452.

Goss-Custard, J. D., R. W. G. Caldow, R. T Clarke, S. E. A. le V. dit Durell, and W. J. Sutherland. 1995a. Deriving population parameters from individual variations in foraging behaviour. I. Empirical game theory distribution model of oystercatchers Haematopus ostralegus feeding on mussels Mytilus edulis. Journal of Animal Ecology 64:265276.

Goss-Custard, J. D., R. W. G. Caldow, R. T. Clarke, and A. D. West. $1995 b$. Deriving population parameters from individual variations in foraging behaviour. II. Model tests and population parameters. Journal of Animal Ecology 64: 277-289.

Grill, C. P., and S. A. Juliano. 1996. Predicting species interactions based on behaviour: predation and competition in container-dwelling mosquitoes. Journal of Animal Ecology 65:63-76.

Hassell, M. P. 1971. Mutual interference between searching insect parasites. Journal of Animal Ecology 40:473-486.

Hay, M. E., and W. Fenical. 1988. Marine plant-herbivore interactions: the ecology of chemical defense. Annual Review of Ecology and Systematics 19:111-145.

Heck, K. L., and T. A. Thoman. 1981. Experiments on predator-prey interactions in vegetated aquatic habitats. Journal of Experimental Marine Biology and Ecology 53:125-134.

Hines, A. H., A. M. Haddon, and L. A. Weichert. 1990. Guild structure and foraging impact of blue crabs and epibenthic fish in a subestuary of Chesapeake Bay. Marine Ecology Progress Series 67:105-126.

Hines, A. H., and T. G. Wolcott. 1990. Blue crab movement and feeding measured by ultrasonic telemetry. Bulletin of Marine Science 46:246 (abstract).

Holbrook, S. J., and R. J. Schmitt. 1988. The combined effects of predation risk and food reward on patch selection. Ecology 69:125-134.

Houston, A., C. Clark, J. McNamara, and M. Mangel. 1988. Dynamic models in behavioural and evolutionary ecology. Nature (London) 332:29-34.

Jachowski, R. L. 1974. Agonistic behavior of the blue crab, Callinectes sapidus Rathbun. Behaviour 50:232-253.

Judson, O. P. 1994. The rise of the individual-based model in ecology. Trends in Ecology and Evolution 9:9-14.

Kerfoot, W., and A. Sih, editors. 1987. Predation: direct and indirect impacts on aquatic communities. University Press of New England, Hanover, New Hampshire, USA.

Kneib, R. T. 1984. Patterns of invertebrate distribution and abundance in the intertidal saltmarsh: causes and questions. Estuaries 7:392-412.

- 1988. Testing for indirect effects of predation in an intertidal soft-bottom community. Ecology 69:1795-1805.

Kohler, S. L., and M. A. McPeek. 1989. Predation risk and the foraging behavior of competing stream insects. Ecology 70:1811-1825.

Kvitek, R. G., J. S. Oliver, A. R. DeGange, and B. S. Anderson. 1992. Changes in Alaskan soft-bottom prey communities along a gradient in sea otter predation. Ecology 73:413-428.

Irons, D. B., R. G. Anthony, and J. A. Estes. 1986. Foraging strategies of glaucous-winged gulls in a rocky intertidal community. Ecology 67:1460-1474.

Laughlin, R. A. 1982. Feeding habits of the blue crab, Callinectes sapidus Rathbun, in the Apalachicola estuary, Florida. Bulletin of Marine Science 32:807-822.

Leber, K. M. 1985. The influence of predatory decapods, refuge, and microhabitat selection on seagrass communities. Ecology 66:1951-1964.

Levin, S. A. 1992. The problem of pattern and scale in ecology. Ecology 73:1943-1967.

Lima, S. L., and L. M. Dill. 1990. Behavioral decisions made under the risk of predation: a review and prospectus. Canadian Journal of Zoology 68:619-640.

Lipcius, R. N., and A. H. Hines. 1986. Variable functional responses of a marine predator in dissimilar homogeneous microhabitats. Ecology 67:1361-1371.

MacArthur, R. H., and E. Pianka. 1966. On optimal use of a patchy environment. American Naturalist 100:603-609. 
MacKenzie, C. L., Jr. 1977. Predation on the hard clam Mercenaria mercenaria populations. Transactions of the American Fisheries Society 106:530-537.

Mangel, M., and C. Clark. 1988. Dynamic modelling in behavioral ecology. Princeton University Press, Princeton, New Jersey, USA.

Mansour, R. A., and R. N. Lipcius. 1991. Density-dependent foraging and mutual interference in blue crabs preying upon infaunal clams. Marine Ecology Progress Series 72:239_ 246.

McNamara, J. M., and A. I. Houston. 1985. Optimal foraging and learning. Journal of Theoretical Biology 117:231-249.

McNamara, J. M., and A. I. Houston. 1986. The common currency for behavioral decisions. American Naturalist 127:372-374.

Menge, B. A. 1978a. Predation intensity in a rocky intertidal community. Relation between predator foraging activity and environmental harshness. Oecologia 34:1-16.

$1978 b$ Predation intensity in a rocky intertidal community. Effect of algal canopy, wave action and desiccation on predator feeding rates. Oecologia 34:17-35.

. 1983. Components of predation intensity in the low zone of a New England rocky intertidal region. Oecologia 58: $141-155$.

Menge, B. A., E. L. Berlow, C. A. Blanchette, S. A. Navarrete and S. B. Yamada. 1994. The keystone species concept: variation in interaction strength in a rocky intertidal habitat. Ecological Monographs 64:249-286.

Menge, B. A., and J. Lubchenco. 1981. Community organization in temperate and tropical rocky intertidal habitats: prey refuges in relation to consumer pressure gradients. Ecological Monographs 51:429-450.

Micheli, F. 1995. Behavioural plasticity in prey-size selectivity of the blue crab Callinectes sapidus feeding on bivalve prey. Journal of Animal Ecology 64:63-74.

- 1996. Predation intensity in estuarine soft bottoms: between-habitat comparisons and experimental artifacts. Marine Ecology Progress Series 141:295-302.

Milinski, M., and R. Heller. 1978. Influence of a predator on optimal foraging behaviour of sticklebacks (Gasterosteus aculeatus L.). Nature 275:642-644.

Mittelbach, G. G. 1988. Competition among refuging sunfishes and effects of fish density on littoral zone invertebrates. Ecology 69:614-623.

Moody, K. E. 1994. Patterns of predation on juvenile blue crabs in lower Chesapeake Bay. Dissertation. College of William and Mary, Williamsburg, Virginia, USA.

Morin, P. J. 1986. Interactions between intraspecific competition and predation in an amphibian predator-prey system. Ecology 67:713-720.

Nye, L. A. 1990. Telemetric analysis of foraging behavior of blue crabs. Bulletin of Marine Science 46:248.

Oliver, J. S., and P. N. Slattery. 1985. Destruction and opportunity on the sea floor: effects of gray whale feeding. Ecology 66:1965-1975.

Paine, R. T. 1966. Food web complexity and species diversity. American Naturalist 100:65-75.

1969. A note on trophic complexity and community stability. American Naturalist 103:91-93.

Palumbi, S. R., and L. A. Freed. 1988. Agonistic interactions in a keystone predatory starfish. Ecology 69:1624-1627.

Peckarsky, B. L., and M. A. Penton. 1989. Mechanisms of prey selection by stream-dwelling stoneflies. Ecology $\mathbf{7 0}$ : 1203-1218.

Peters, R. H. 1991. A critique for ecology. Cambridge University Press, Cambridge, UK.

Peterson, C. H. 1979. Predation, competitive exclusion, and diversity in the soft-sediment benthic communities of estuaries and lagoons. Pages 233-264 in R. J. Livingston, editor. Ecological Processes in Coastal Marine Systems. Plenum, New York, New York, USA.

- 1982. Clam predation by whelks (Busycon spp.): experimental test of the importance of prey size, prey density, and seagrass cover. Marine Biology 66:159-170.

1990. On the role of ecological experimentation in resource management: managing fisheries through mechanistic understanding of predator feeding behaviour. Pages 821-846 in R. N. Hughes, editor. Behavioural mechanisms of food selection. North American Treaty Organization Advanced Science Institute Series. Volume G 20, SpringerVerlag, Berlin Heidelberg, Germany.

1991. Intertidal zonation of marine invertebrates in sand and mud. American Scientist 79:236-249.

Peterson, C. H., and P. E. Renaud. 1989. Analysis of feeding preference experiments. Oecologia 80:82-86.

Peterson, C. H., and G. A. Skilleter. 1994. Control of foraging behavior of individuals within an ecosystem context: the clam Macoma balthica, flow environment, and siphoncropping fishes. Oecologia 100:256-267.

Peterson, C. H., H. C. Summerson, and P. B. Duncan. 1984. The influence of seagrass cover on population structure and individual growth rate of a suspension-feeding bivalve, Mercenaria mercenaria. Journal of Marine Research 42: 123-138.

Pierce, G. J., and J. G. Ollason. 1987. Eight reasons why optimal foraging theory is a complete waste of time. Oikos 49:111-118.

Power, M. E. 1990. Effects of fish in river food webs. Science 250:411-415.

1992. Habitat heterogeneity and the functional significance of fish in river food webs. Ecology 73:1675-1688.

Power, M. E., T. L. Dudley, and S. D. Cooper. 1989. Grazing catfish, fishing birds, and attached algae in a Panamanian stream. Environmental Biology of Fishes 26:285-294.

Prescott, R. C. 1990. Sources of predatory mortality in the bay scallop Argopecten irradians (Lamarck): interactions with seagrass and epibiotic coverage. Journal of Experimental Marine Biology and Ecology 144:63-83.

Pyke, G. H. 1984. Optimal foraging theory: a critical review. Annual Review of Ecology and Systematics 15:523-575.

Robles, C. 1987. Predator foraging characteristics and prey population structure on a sheltered shore. Ecology 68: 1502-1514.

Robles, C., R. Sherwood-Stephens, and M. Alvarado. 1995. Responses of a key intertidal predator to varying recruitment of its prey. Ecology 76:565-579.

Schoener, T. W. 1993. On the relative importance of direct vs. indirect effects in ecological communities. Pages 365411 in H. Kawanabe, J. E. Cohen, and K. Iwaski, editors. Mutualism and community organization. Oxford Scientific, Oxford, UK.

Sih, A. 1980. Optimal behavior: can foragers balance two conflicting demands? Science 210:1041-1043.

1981. Stability, prey density, and age-dependent interference in an aquatic insect predator, Notonecta hoffmanni. Journal of Animal Ecology 50:625-636.

Sih, A., P. Crowley, M. McPeek, J. Petranka, and K. Strohmeier. 1985. Predation, competition, and prey communities: a review of field experiments. Annual Review of Ecology and Systematics 16:269-311.

Skilleter, G. A., and C. H. Peterson. 1994. Control of foraging behavior of individuals within an ecosystem context: the clam Macoma balthica and interactions between competition and siphon cropping. Oecologia 100:268-278.

Smith, L. D. 1995. Effects of limb autotomy and tethering on juvenile blue crab survival from cannibalism. Marine Ecology Progress Series 116:65-74.

Sponaugle, S., and P. Lawton. 1990. Portunid crab predation 
on juvenile hard clams: effects of substrate type and prey density. Marine Ecology Progress Series 67:43-53.

Stephens, D. W., and J. R. Krebs. 1986. Foraging theory. Princeton University Press, Princeton, New Jersey, USA.

Sutherland, W. J. 1983. Aggregation and the 'ideal free' distribution. Journal of Animal Ecology 52:821-828.

Underwood, A. J. 1981. Techniques of analysis of variance in experimental marine biology and ecology. Oceanography and Marine Biology Annual Review 19:513-605.

Underwood, A. J., and E. J. Denley. 1984. Paradigms, explanations, and generalizations in models for the structure of intertidal communities on rocky shores. Pages 151-180 in D. R. Strong Jr. et al., editors. Ecological communities conceptual issues and the evidence. Princeton University Press, Princeton, New Jersey, USA.

Virnstein, R. W. 1977. The importance of predation by crabs and fishes on benthic infauna in Chesapeake Bay. Ecology 58: $1199-1217$.

Weissburg, M. J., and R. K. Zimmer-Faust. 1993. Life and death in moving fluids: hydrodynamic effects on chemosensory-mediated predation. Ecology 74:1428-1443.

Werner, E. E. 1992. Individual behavior and higher-order species interactions. American Naturalist 140:S5-S32.

Werner, E. E., and M. A. McPeek. 1994. Direct and indirect effects of predators on two anuran species along an environmental gradient. Ecology 75:1368-1382.

Woodin, S. A. 1978. Refuges, disturbance and community structure: a marine soft-bottom example. Ecology 59:274284.

Wootton, J. T. 1993. Indirect effects and habitat use in an intertidal community: interaction chains and interaction modifications. American Naturalist 141:71-89. 